\title{
A rede de solução de problemas do peronismo
}

Peronism's problem-solving network

\section{O argumento ${ }^{1}$}

Alguns moradores de Vila Paraíso² resolvem seus problemas de sobrevivência cotidiana (comida e medicamentos) por meio dos favores, bens e serviços providos pelos mediadores políticos locais.

\section{Os protagonistas}

Matilde: vereadora do município de Cóspito. Proprietária e dirigente da Unidade Básica (UB) Três Gerações e principal referente política em Vila Paraíso e zonas próximas. Foi secretária política do Partido Justicialista em um distrito vizinho e secretária de Ação Vicinal na Prefeitura de Cóspito ${ }^{3}$.

Adolfo: marido de Matilde. Subsecretário de Obras e Serviços Públicos na Prefeitura de Cóspito.

Pedro e Paco: filhos de Matilde. Pedro é funcionário público na Prefeitura de Cóspito e secretário privado de Adolfo. Paco é presidente do Centro

* É professor do Departamento de Sociologia da Universidade do Texas (EUA). E-mail: auyero@austin. utexas.edu.

1 Texto traduzido do original "Conocián a Matilde: la red de solución de problemas", publicado como capítulo 3 do livro La política de los pobres: Ias prácticas clientelistas del peronismo (Buenos Aires: Manantial, 2001). Direitos cedidos por Ediciones Manantial. Traduzido por Naila Freitas. Revisão da tradução por Luis Felipe Miguel

2 Os nomes do bairro e do município foram trocados pelo autor, a fim de evitar a identificação de suas personagens. Trata-se de um bairro pobre de um município da grande Buenos Aires (NRT).

3 As UBs são comitês partidários do Partido Justicialista. Podem coexistir vários no mesmo bairro. Os referentes são mediadores políticos, semelhantes aos cabos eleitorais brasileiros, mas com um estatuto superior (NRT). 
Cultural Jauretche, localizado a meia quadra da UB de Matilde, na frente da sua própria casa.

Mimí: irmã de Matilde. Coordenadora distrital do Plano Vida (PV). Esse plano distribui diariamente leite, ovos, cereais e açúcar nos bairros pobres de Buenos Aires, mediante delegadas de quarteirão. Mimí coordena as 23 delegadas de quarteirão de Vila Paraíso.

Ingrid: empregada doméstica de Matilde, secretária do Centro Cultural Jauretche e delegada de quarteirão do Plano Vida.

Marcela: secretária privada de Matilde.

Rafael Bianco: conhecido como "Cholo". Trabalha com/para Matilde há quatro anos. É um militante peronista e referente local. É proprietário e dirigente de uma UB na Quinta Rua, a área mais pobre de Vila Paraíso.

Juan Pisutti: conhecido como "Juancito". Funcionário público na Prefeitura de Cóspito e presidente da UB Perón Vive. Também é referente em Vila Paraíso e foi secretário geral da principal sociedade de fomento da vila.

Andrea Andrade: funcionária pública na Prefeitura de Cóspito, secretária da UB Fernando Fontana, localizada no centro de Vila Paraíso.

Juana Medina: acaba de abrir uma UB de nome "Chacho Peñaloza", na Vila.

Rodolfo Fontana: conhecido publicamente como "Rolo". Prefeito de Cóspito e presidente do Partido Justicialista desse distrito.

Hilda "Chiche" González de Duhalde: esposa do governador e diretora do Plano Vida e de outros programas de assistência social. Presidenta honorária do Conselho Provincial da Família e Desenvolvimento Humano.

Eduardo Duhalde: governador da província de Buenos Aires. 


\section{“Tudo pela felicidade de uma criança”}

A tarefa consiste em captar uma realidade oculta que vela a si mesma ao desvelar-se, que se oferece aos observadores apenas na forma anedótica da interação que a dissimula.

Pierre Bourdieu

(Bourdieu e Wacquant, 1992, p. 256)

No Dia das Crianças, Matilde e seus seguidores organizaram três atos em diferentes áreas de Vila Paraíso. Às dez da manhã, Matilde, Adolfo, Pedro e Paco, Mimí, Ingrid e Marcela chegam à UB de Cholo, na Quinta Rua.

Adolfo veio na camioneta, junto com Oreja - membro do grupo conhecido como "A Banda de Matilde" - e Patón. Patón é funcionário público na Subsecretaria de Obras Públicas. Usualmente dirige o caminhão que leva água potável para a Quinta Rua. Assim que estacionam a camioneta, Patón e Oreja descarregam sacos de leite, sacolas com brinquedos e duas bicicletas. O leite pertence ao Plano Vida, o maior dos programas de distribuição de alimentos que desenvolve o governo provincial. Não se supõe que esse leite seja usado para propósitos partidários; pelo menos isso é o que a esposa do governador repete semanalmente. Contudo, preparar o chocolate quente para as crianças da vila em "seu dia" é uma "boa causa", suficientemente nobre para justificar o desvio de recursos estatais para uso político partidário.

A mesma utilização "privada" dos recursos públicos se aplica à camioneta. Na parte traseira está escrito: "Unidade adquirida com o que você paga. A serviço do povo”. Um jornal local denunciou recentemente que essa mesma camioneta foi utilizada por um grupo de jovens para fazer campanha política contra um vereador do Partido Radical. Depois de descrever o que denominou "atividades duvidosas" desse grupo de jovens, a nota jornalística terminava com uma pergunta retórica: “A serviço de qual povo?”. O grupo também é encarregado da propaganda política: pintam paredes e penduram faixas. Pedro - um dos filhos de Matilde - é quem dirige e paga os integrantes. Um dos membros da banda me disse: "Ele faz o trabalho sujo". No dia anterior ao Dia das Crianças, escutei Matilde dizer para Pedro: "Nessa parede, onde está pintado o nome de Pedele [...], quero meu nome aî". Nessa mesma noite, Pedro levou "os rapazes de Matilde" até essa parede, com a mesma camioneta, e eles pintaram o cartaz que diz: "Sempre com Rolo. A banda de Matilde". 
Pedro também está encarregado da distribuição de vinho, cigarros de tabaco e/ou maconha entre os membros da banda; prepara o churrasco depois dos atos públicos aos quais a banda assiste e depois de cada uma das pichações noturnas ${ }^{4}$.

Todos os meses, Cholo recebe leite em pó do Plano Materno-Infantil ${ }^{5}$ para distribuir entre as mulheres grávidas e crianças de um a cinco anos que moram em "sua" área. Também obtém de Matilde, uma vez por mês, pacotes de comida (macarrão, arroz, erva-mate, polenta etc.) e medicamentos (calmantes, aspirinas, antibióticos etc.). Recebe sacolas extras de comida cada vez que há um ato público do partido. As duas bicicletas que hoje trouxe Matilde são os prêmios de uma rifa que ela e Cholo organizaram na tarde desse dia entre as crianças que assistiram ao "seu Dia das Crianças". Matilde deu a Cholo as bicicletas e outros brinquedos (bolas, bonecas etc.) para que fossem rifados entre as crianças da Quinta Rua.

Na frente da UB de Cholo, os palhaços trazidos por Matilde fazem suas atuações em um precário cenário, ornamentado por coloridos balões estampados com a cara do prefeito e duas frases, uma atribuída a Juan Perón ("As únicas privilegiadas são as crianças"), e outra que pertence a Rolo Fontana (“Tudo pela felicidade de uma criança”). O Dia das Crianças é uma boa ocasião para passar por alto dessas insignificantes confusões entre a política partidária e as atividades do Estado. Vale tudo pela felicidade de uma criança: estampar o rosto nos balões com que elas brincam, desviar recursos dos programas estatais, misturar a política partidária com as responsabilidades oficiais.

Mais tarde, nesse mesmo cenário, Matilde oferecerá um curto, mas muito significativo, discurso. Começa dizendo que o prefeito Rolo não pôde vir para comemorar com eles, "mas vocês o veem todos os dias, ou seja, não é um grande problema”. Para comemorar o Dia das Crianças, ela sustenta que "as pessoas devem estar junto com suas famílias [...]. Nós temos um costume: trabalhamos como uma família, para a família e com a família. Como sempre digo, o povo, o governo e as instituições intermediárias [...] juntos [...] vamos conseguir grandes coisas".

\footnotetext{
Maconha, cigarros, vinho e churrascos são, pelo que sei, as recompensas mais comuns que os membros da banda obtêm de Matilde. A expectativa de um cargo público na prefeitura e a "proteção geral" frente à polícia também funcionam como recompensa virtual para muitos dos membros da banda. Como disse um jovem do bairro: "Eles estão aí (na UB) para que a polícia não nos pegue". 
Mais tarde, no limite sul de Vila Paraíso, Matilde e toda a sua família irão se encontrar com o prefeito em outra comemoração do Dia das Crianças, organizada por Juana Medina, militante da UB Chacho Peñaloza. Pedele (vereador peronista de um município vizinho) é quem financia a organização desse ato (pagando pelas bicicletas para as rifas e pela banda musical Los Pasteles Verdes, que toca depois do discurso do prefeito). Com os retratos de Juan e Eva Perón atrás, o prefeito faz um reconhecimento público a Pedele, como o organizador do ato, e diz:

[Esta] festa [...] que é dar um sorriso, dar amor a todas as crianças, porque estamos repetindo o que disse uma grande mulher argentina que todos levamos dentro dos nossos corações, Eva Perón, quando disse que em nossa pátria as únicas privilegiadas são as crianças [...]. Para isso estamos trabalhando em Cóspito, para dar mais ajuda, mais bem-estar ao povo, e ainda mais neste momento, em que o povo está atravessando uma situação um pouco difícil, mas aqui está o governo justicialista, com seus governantes [...], trabalhando para dar mais ajuda e mais felicidade ao povo [...]. Isso é o que tem que fazer o peronismo, isso é o que tem que fazer em favor da gente humilde, dos trabalhadores, dos idosos, das crianças, fazer simplesmente o que fez Juan Perón e o que fez Eva Perón.

Às duas da tarde voltamos para a casa de Matilde, depois de um extenuante Dia das Crianças que incluiu palhaços, números musicais, rifas, discursos e chocolate quente. Exatamente quando ia me retirar, Matilde diz: "Percebeu? Depois de tudo o que você viu [...] os votinhos vêm, não preciso ir buscá-los [...], os votos vêm sozinhos". Ela conseguiu sua cadeira de vereadora nas últimas eleições de 1995, nas quais o PJ obteve 60\% dos votos em Vila Paraíso. Uma porcentagem mais do que considerável, levando-se em conta que o PJ obteve 50,6\% na cidade de Cóspito (eleições para prefeito).

Matilde é o que a literatura sobre clientelismo político denominaria mediador político, faz a intermediação entre um patrão - neste caso, Rolo Fontana, o prefeito da cidade de Cóspito - e alguns de seus seguidores. Capitulero, no Peru das décadas de 1930 e 40 (Stein, 1980); cabo eleitoral, no Brasil dos anos 1930 em diante (Conniff, 1981; Mouzelis, 1985; Roniger, 1990; ver também Gay, 1994); gestor, padrinho político ou cacique no México em vários momentos de sua história moderna (Carlos e Anderson, 1991; Ugalde, 1973; Cornelius, 1973; Roniger, 1990); capitães de vizinhança, nas máquinas políticas de Chicago e de outras grandes cidades norte-americanas 
(Kornblum, 1974; Guterbock, 1980; Katznelson, 1981; ver também Knoke, 1990); caudilho de bairro, nos partidos radical e conservador na Argentina dos anos 1920 e 30 (Rock, 1975, 1972; Walter, 1985; Bitran e Schneider, 1991); referente ou puntero peronista, na Argentina dos anos 1990. Apesar de haver significativas diferenças entre eles, sua função é essencialmente a mesma: operam como mediadores, como "go-betweens". Fazem a intermediação entre seus caudilhos, chefes politicos, ward bosses e os clientes. Os referentes, que são especialistas em manipulação de informação e de pessoas, usufruem do poder posicional que acompanha sua função mediadora e canalizam recursos do patrão para os clientes, e votos e apoio dos clientes para a pessoa que controla os recursos materiais e simbólicos.

Em Vila Paraíso, há cinco unidades básicas, com seus respectivos mediadores políticos: a UB Chacho Peñaloza,, de Juana Medina, a UB Perón vive, de Juan Pisutti, a UB Fernando Fontana, de Andrea Andrade, a UB 27 de Abril, de Cholo, e a UB Três Gerações, de Matilde ${ }^{7}$. Apesar de esta última estar localizada fora dos limites administrativos da vila, seu trabalho político/social está dirigido à população dela. As unidades básicas estão geograficamente dispersas no território da vila. Não apenas fazem trabalho político durante as eleições, mas também são centros de distribuição de medicamentos e comida. Os mediadores fazem favores o ano todo. Durante a última década, essas unidades básicas passaram a ser os centros de resolução de problemas mais importantes da localidade.

Apesar de a forma das redes de resolução de problemas e suas funções serem similares, uma vez que olhamos mais de perto vemos que os mediadores diferem em dois aspectos fundamentais. É importante explorar essas diferenças, porque elas nos permitem dar conta do dinamismo do mundo

6 Como me sugeriu Robert Gay em uma conversação, uma diferença importante entre os mediadores é que alguns deles estão "ligados"a um partido político específico (ou a um patrão específico), como é o caso dos punteros peronistas. Como Gay $(1990,1994)$ demonstra, a lealdade do cabo eleitoral para com um partido político específico é bastante menos sólida. O mediador peronista está localizado, de algum modo, entre dois tipos ideais de membros de uma organização: na terminologia de Pizzorno (e Hirschman), entre o membro de "alta lealdade" e o "identifier". Para uma resenha das representações dos mediadores, caciques e outros tipos de patrões na literatura latino-americana, ver Nason (1973).

7 Na verdade, é possível ver muitas outras unidades básicas na vila, quase uma por quadra. São aquelas que, na linguagem política local, são chamadas de fungos, que aparecem durante os períodos eleitorais e desaparecem assim que se finaliza a campanha, deixando para trás apenas os cartazes de propaganda, como rastros nas paredes das casas. 
da mediação política personalizada. Em particular, prestarei atenção às distinções que emergem: a) do acesso diferencial aos recursos de cima e de baixo que os mediadores têm, mostrando que esse acesso coincide com seu poder (e com os diversos tipos de mediadores realmente existentes); e b) da cooperação ou da competição entre os mediadores, mostrando que essa cooperação/competição está relacionada com a superposição ou exclusividade das suas redes.

A rede de Matilde é a mais importante em Vila Paraíso - transformando-a na "grande mulher" da vila, no sentido que Sahlins (1977) dá ao termo. Sua rede superpõe-se à mais recente do Plano Vida.

\section{Sobrevivendo na vila}

Em contextos de privação material extrema e desproletarização, como fazem os moradores com nula ou escassa renda, sem pensão, aposentadoria ou algum outro benefício, para obter seus meios de vida, basicamente comida e medicamentos? Existe alguma instituição ou pessoa dentro ou fora da vila à qual possam recorrer para obter alguma ajuda? Que contatos ou relações estabelecem para obter seus meios de vida? Quem tem contato com quem? De que maneira a forma e o conteúdo destas relações impactam o comportamento e as percepções dos envolvidos?

Enzo Mingione deu o nome de "economia popular" a essa "combinação de atividades realizadas para a subsistência direta ou para obter uma escassa renda" (Mingione, 1991, p. 87). Em Vila Paraíso, essas atividades incluem a criação de animais, feiras de alimentos, consertos caseiros, trabalho industrial terceirizado etc. As redes familiares e de bairro "sempre possibilitaram que estas diversas atividades coagulem em um modo de vida pobre, mas protegido" (Mingione, 1991, p. 87). Em um nível mais geral, Uehara assinala que "a ajuda material e a intangível providas por membros da família e por outros que operam fora das arenas profissionais ou burocráticas é uma parte central e viável da vida social contemporânea" (Uehara, 1990, p. 521). Em seu estudo sobre Cerrada del Cóndor, na Cidade do México, Lomnitz (1975, 1988) também observa que as redes sociais baseadas na residência e no parentesco funcionam como um sistema de seguridade social complementar para a sobrevivência individual entre os moradores do bairro. "As redes próximas de reciprocidade com vizinhos e parentes" (Friedman e Salguero, 1988 , p. 11) são elementos bastante estudados na maneira de entender como 
as pessoas enfrentam o desafio da sobrevivência, e de examinar quais são as relações que se estabelecem nesse processo.

As redes informais de reciprocidade têm sido profunda e profusamente estudadas na América Latina, muitas vezes como fontes das "estratégias de sobrevivência" desenvolvidas pelos pobres urbanos ou rurais (Lomnitz, 1975, 1988; Margulis, 1981; Hintze, 1989). As redes políticas também têm sido estudadas para o caso desta parte do continente e em outros lugares do mundo (Conniff, 1981; Burgwald, 1996; Kornblum, 1974; Guterbock, 1980; Katznelson, 1981; Knoke, 1990). Contudo, as relações que existem entre as redes informais de ajuda recíproca e as redes políticas foram pouco examinadas. O estudo de Singerman (1995) sobre o setor popular no Cairo (o sha’b) constitui uma provocadora exceção. Em sua pesquisa extremamente detalhada sobre a maneira pela qual as redes informais "conectam" o lar e a família estendida com a burocracia pública e as instituições privadas, aponta uma nova direção na compreensão da "política popular". De acordo com sua análise, devemos penetrar sob as instituições formais se queremos entender as culturas políticas dos grupos populares. Segundo ela, as "redes informais" constituem "avenidas de participação" não consideradas do sha'b no espaço público egípcio.

Em Vila Paraíso, e em tantos outros territórios de relegação urbana na conurbação bonaerense, assistimos a uma crescente superposição de redes informais de sobrevivência e redes políticas. Dizendo de maneira crua, as unidades básicas, os referentes políticos e os programas estatais de ajuda transformaram-se na fonte de recursos que circulam dentro das redes informais de sobrevivência. Com o desaparecimento do trabalho assalariado e o esvaziamento da economia da vila, as redes informais de ajuda mútua estão "dessangrando-se mortalmente". Aqueles que tinham emprego e podiam sustentar familiares ou amigos temporariamente sem trabalho hoje também estão desempregados. Os moradores da vila recorrerão ao Estado local ou - o que, como veremos, vem a ser a mesma coisa - à UB mais próxima para obter medicamentos ou comida. Em outras palavras, as estratégias de sobrevivência estão cada vez mais ancoradas nas redes políticas. Por redes políticas entendo, seguindo D. Knoke (1990) e M. Granovetter (1973), um conjunto de contatos regulares ou conexões sociais similares entre indivíduos ou grupos, nos quais pelo menos um deles é membro de um partido político ou é um funcionário estatal. As estratégias de sobrevivência estão ancoradas 
em uma rede política de resolução de problemas porque se expressam nas interações entre agentes de um partido político ou funcionários estatais e os moradores da vila.

A crescente relevância das redes políticas não significa que as redes de ajuda mútua tenham desaparecido. Em Vila Paraíso, essas redes ainda são centrais nas estratégias de sobrevivência de seus moradores. Mais de 20\% dos consultados mencionam seus parentes como fontes de ajuda no caso de precisarem de algum medicamento ${ }^{8}$. Muitos dos entrevistados recorrem a parentes ou amigos quando precisam de comida. Mesmo uma observação superficial dará conta do fato de que os favores recíprocos abundam na economia popular de Vila Paraíso. Contudo, com o aumento sideral do desemprego e do subemprego, e com a generalizada redução de renda, essas redes estão sendo progressivamente esvaziadas de seus recursos. Quando a exclusão/rejeição do mercado laboral deixa de ser temporária (como testificam os $60 \%$ de desemprego e subemprego e o longo tempo em que estão desempregados) e a redução da renda afeta todos e cada um dos postos de trabalho que a mão de obra não qualificada de Vila Paraíso pode obter, a economia social da vila perde sua função tradicional. Em outras palavras, a economia popular da vila, para falar como Mingione, deixa de ser um colchão que ajuda a amortecer os impactos da severidade ou, melhor dizendo, da violência econômica. As avenidas que costumavam vincular a economia da vila com o trabalho assalariado estão interrompidas e o fluxo de dinheiro que costumava entrar no espaço da vila, transformando-se no "sangue" dessas redes de reciprocidade, diminui de maneira drástica. De uma forma similar à que afeta o gueto negro norte-americano, "os indivíduos longamente excluídos do trabalho assalariado em bairros marginalizados não podem recorrer ao apoio informal coletivo enquanto esperam um trabalho que, realmente, pode não vir nunca" (Wacquant, 1996, p. 9).

Quase $40 \%$ dos moradores da vila recebem comida para eles ou seus filhos/as de um ou mais dos programas estatais de assistência que existem. Esses programas incluem a distribuição de leite, ovos, cereais e macarrão (Plano Vida), leite em pó (Plano Materno-Infantil), macarrão, azeite, polenta, erva-mate, lentilhas etc. (Plano Asoma), e queijo, verduras, macarrão, azeite e outros produtos (Plano Pró-Bem-estar). Além desses programas, algumas

8 Os dados vêm de uma pesquisa de 300 casos que realizei nos meses de setembro e outubro de 1996. 
pessoas vão até a prefeitura, onde, duas vezes por mês, a Secretaria de Ação Social distribui nove produtos alimentícios por pessoa (açúcar, arroz, farinha, macarrão, polenta, lentilhas, azeite e erva-mate). Segundo minha pesquisa, quase metade da população sabe sobre essa distribuição de comida que é feita no anexo do edifício municipal. Trinta por cento dos que conhecem essa distribuição já foram buscar os "nove quilos" pelo menos uma vez durante o último ano. As delegadas de quarteirão, por sua vez, são muito conhecidas na vila desde o lançamento do programa, em dezembro de 1995. Quase 60\% da população consultada mencionam as "delegadas do vida" como a mais importante fonte de distribuição de comida na vila.

Para os medicamentos, as pessoas recorrem aos seus parentes $(21 \%)$; aqueles que têm emprego formal vão à sua obra social (20\%). Outros recorrem à prefeitura, ao centro de saúde local (18\%), aos locais do PJ ou a algum referente (6\%).

Uma ilustração da dramática deterioração das condições de vida dos moradores da vila pode ser vista na recente abertura de um refeitório infantil na igreja católica da vila. Por volta de noventa meninos e meninas almoçam semanalmente ali. É importante destacar que esse refeitório é financiado quase totalmente pela Secretaria de Ação Social municipal. Como Nora, a pessoa encarregada do refeitório e da Cáritas local, explicava: “90\% do refeitório são subvencionados pela prefeitura”. Também reconhece que a Secretaria de Ação Social não envia produtos lácteos, frutas ou verduras: "Se queremos fazer macarrão com manteiga, temos que comprar a manteiga". Como veremos mais adiante, os referentes locais tentam tirar vantagem dessas necessidades para aumentar seu poder.

A Cáritas também multiplica suas atividades. ${ }^{9}$ Todos os meses, presta assistência a aproximadamente cem famílias. O padre local obteve recentemente uma doação da Cruz Vermelha, ou seja, a Cáritas também distribui medicamentos de forma gratuita. Tanto o padre local quanto a mulher encarregada da Cáritas concordam em que durante o último ano as demandas de comida e medicamentos aumentaram substancialmente. Assinala o sacerdote:

Crescimento que também acontece na Cáritas Nacional. Como menciona Monsenhor Rey, a quantidade de crianças que a Cáritas alimenta em seus refeitórios aumentou de 50.000 para 400.000 (oito vezes) nos últimos três anos. Clarín Digital, 19 de novembro de 1996. 
Na Cáritas costumávamos ajudar as famílias por um período de tempo limitado, vamos dizer, por três meses, até que resolviam a situação difícil pela qual estavam passando, por exemplo, se tinham sido demitidos. Mas agora simplesmente não podemos deixar de ajudá-los, e há mais gente que vem e não damos conta.

Embora não reconheçam sua crescente dependência dos recursos estatais, ambos admitem que seus recursos diminuem diariamente. Como diz Nora: "Aqui estamos sozinhos: porque não estamos recebendo a ajuda que costumávamos ter de outras paróquias vizinhas. A ajuda é cada vez menor". Tanto o padre quanto Nora reconhecem que a igreja não pode satisfazer essa crescente demanda, e apontam as unidades básicas como fontes de possíveis soluções para a escassez extrema que sofrem os moradores. Ambos também criticam essas unidades básicas pelo "preço" que o povo deve pagar para obter essas soluções. Nora traça uma distinção entre as práticas distributivas da igreja e as do PJ, distinção que nos ajuda a ver uma confusão comum entre o partido e o Estado:

A diferença entre nós (Cáritas) e a UB que reparte comida é que nós não perguntamos a ninguém se vem rezar, se é católico ou não; temos que ajudá-lo porque é um ser humano. Parece que a prefeitura empurra um pouquinho para fazerem política, para irem aos atos, para que se filiem [...] e, se você não quer, não te dão nada. "Se você vem aos atos, vamos te ajudar." Essa é a diferença com nós. Temos muitas mães que são evangélicas, mas nós não questionamos isso, não temos nenhuma razão para fazê-lo.

Como é sua relação com os punteros peronistas?, perguntei a Mariano, o padre local. "É a mesma que tenho com a Cruz Vermelha Internacional. Eu peço, e se eles me dão coisas para o pessoal, aceito. Mas todo mundo sabe que não estou na política. A igreja não pode se meter em política." Embora a igreja e o PJ sejam as principais instituições que resolvem problemas na vila (a primeira cada dia mais dependente dos recursos providos pelo Estado peronista), ambas não competem entre si no sentido estrito do termo. Por um lado, os referentes e o padre estão em busca de diferentes tipos de lealdades, e competem com outras instituições por essas lealdades: outros partidos e correntes internas, no caso dos referentes; igrejas evangélicas que se multiplicaram durante a última década, no caso do padre. Por outro lado, segundo a perspectiva dos moradores da vila, ambas as redes são meios alternativos (não mutuamente excludentes) para obter recursos. "Sou consciente de que 
as famílias que obtêm ajuda de Cáritas também recebem coisas da Unidade Básica”, diz Mariano.

Em Vila Paraíso, como em tantos outros bolsões de pobreza urbana da conurbação bonaerense (ver Levitsky, 1997), uma das maneiras de satisfazer as necessidades básicas de alimentação e saúde dos pobres é por meio do partido político com acesso direto aos recursos estatais (nacionais, provinciais e, neste caso, municipais): o Partido Justicialista. Em bairros pobres, assentamentos e vilas, as unidades básicas são os lugares mais importantes nos quais as necessidades mínimas podem ser satisfeitas e os problemas mais urgentes podem ser resolvidos. Essas unidades básicas dão uma incrível força organizacional ao Partido Peronista e são os lugares onde encontramos os mediadores, conhecidos como punteros ou referentes.

\section{Os mediadores e sua rede}

Bens são usados para estabelecer relações sociais. Mary Douglas

Em "Aspects of group relations in a complex society", Eric Wolf apresenta a ideia de broker cultural. Os brokers, ou mediadores, são "grupos de pessoas que fazem a mediação entre os grupos orientados para a comunidade e os grupos orientados para a nação que operam mediante instituições nacionais" (Wolf, 1956, p. 1066). Os brokers "montam guarda sobre as articulações críticas" (Wolf, 1956, p. 1075) que conectam o sistema local com o todo social mais abrangente. Wolf sustenta que a função básica desses brokers é relacionar indivíduos orientados para a comunidade que desejam estabilizar ou melhorar suas possibilidades de vida, mas que carecem de segurança econômica e de conexões políticas, com indivíduos "orientados para a nação". Esses últimos operam primariamente em termos de "formas culturais complexas padronizadas, como instituições nacionais, mas seu sucesso nestas operações depende do tamanho e da fortaleza do conjunto de seus seguidores pessoais" (Wolf, 1956, p. 1076).

Apesar de ter sido projetada e pensada em relação a sociedades camponesas e muito influenciada pela ideia de sistemas separados, a noção de broker pode ser utilizada para iluminar o papel que os mediadores cumprem dentro dos partidos políticos em âmbitos urbanos: a canalização de recursos, bens e 
serviços do partido ou de uma estrutura estatal particular para o espaço da comunidade ou bairro por meio de uma organização partidária particular. Embora sua posição seja similar, nos âmbitos urbanos a mediação costuma ser menos estável do que em âmbitos rurais. ${ }^{10}$

Em Peasant society and culture, Redfield (1956) observa a existência de hinge groups (grupos-dobradiça), que são similares aos brokers analisados por Wolf. Um hinge group é um conjunto de intermediários culturais ou administrativos que constituem um laço entre a vida local de uma comunidade camponesa e o Estado do qual faz parte. Para Silverman (1977), o conceito de mediador também é central para entender a relação entre a comunidade e a sociedade que a abrange em um período histórico particular. $\mathrm{O}$ conceito de mediador refere-se ao status, que funciona como um laço entre o sistema local e o sistema nacional. $\mathrm{O}$ mediador, em termos interacionais, pode ser visto - de acordo com Silverman - como aquele cuja ação é originada a partir do nível nacional e que origina ação no sistema local. Os mediadores têm funções "críticas" (isto é de direta importância para as estruturas de ambos os sistemas). Essas funções são, como característica básica dos mediadores, executadas por eles com quase exclusividade (Silverman, 1977). Brokers, hinge groups, mediadores, buffers: esses são os termos com os quais a antropologia tem analisado o contato e a interpenetração das culturas camponesas com as culturas nacionais.

Apesar de a distinção "dentro-fora" e "local-nacional" aparecer hoje como problemática, essas diferenças no papel que cumprem os mediadores têm o mérito de nos levar a um tema central relativo à sua posição. Os mediadores - como diria Geertz (1983) do antropólogo - "estão aqui" e "estão ali”; têm pertencimentos de classe social quase similares aos de seus clientes. $O$ fator distintivo nos mediadores é a quantidade acumulada de capital social. Como sustenta Wacquant: "Entre os recursos aos quais os indivíduos podem apelar para implementar estratégias de mobilidade social estão aqueles que potencialmente podem ser proporcionados por seus amantes, parentes e amigos, e pelos contatos que possam desenvolver dentro das associações formais às quais eles pertencem - em suma, os recursos aos quais os indivíduos têm acesso por estarem socialmente integrados em grupos solidários, redes ou organizações, o que Bourdieu chama de 'capital social'” (Wacquant e Wilson, 1989, p. 22; ver também Bourdieu, 1990). O capital social (a quantidade de

10 Isso não quer dizer que em âmbitos rurais as relações patrão-cliente não tenham disputas. Ver Scott (1977a, 1977b) para um exame da maneira como as relações de clientela adquirem ou perdem legitimidade. 
recursos derivada das conexões e do pertencimento a certo grupo) é um aspecto central para efeitos de distinguir os brokers de seus clientes.

Os referentes ou punteros geralmente são proprietários ou alugam uma unidade básica. Matilde, Pisutti, Juana Medina e Rafael Bianco são os donos legais dos locais em que funcionam suas unidades básicas. Andrea Andrade aluga seu local. Todos (exceto Juana) estão empregados na prefeitura e constroem uma rede de seguidores que usualmente coincide com a área geográfica de suas unidades básicas. Da mesma maneira que os ward bosses em Chicago (Guterbock, 1980) e os bandos juvenis nas grandes cidades norteamericanas (Sánchez Jankowski, 1991), os referentes peronistas constroem e defendem um território sobre o qual dizem ser os "governantes". "Sua gente" está em "seu território". Contudo, diferentemente dos bandos e dos chefes políticos, as condutas "ilegais" não constituem - até onde pude investigar - o traço sobressalente da territorialização do domínio do referente. ${ }^{11}$

Usualmente, os mediadores fazem favores (distribuem comida e medicamentos) aos seus potenciais votantes, mas não estão sozinhos nessa tarefa. Eles têm um "círculo íntimo" de seguidores. Esses seguidores são os "satélites pessoais" do mediador, para falar com termos de Sahlins (1977, p. 222). A rede de resolução de problemas consiste em uma série de círculos de forma irregular, que giram em torno do puntero/referente, que está relacionado com os membros de seu "círculo íntimo" por meio de laços fortes de amizade duradoura, de parentesco, real ou fictício. Tanto Matilde quanto Juancito - os referentes mais poderosos de Vila Paraíso - têm essa "rede efetiva" (Epstein, 1969) à sua volta, pessoas com as quais as interações são mais intensas e regulares.

Além de sua família e de sua "banda", Matilde tem um círculo de homens e mulheres que a visitam quase semanalmente e que dela recebem medicamentos. Como Lucina, uma empregada doméstica de Matilde, que teve uma embolia e obteve uma pensão de 110 pesos graças a Matilde, que naquele momento era secretária de Ação Vicinal na Prefeitura de Cóspito. Lucina recebe medicamentos para a pressão. O marido de Matilde (Adolfo) conseguiu um trabalho na Subsecretaria de Obras e Serviços Públicos para o marido de Lucina. Ela passa boa parte de suas tardes no Centro Cultural Jauretche, fazendo bonecos que são vendidos ou distribuídos em ocasiões especiais (o Dia das Crianças, por exemplo).

Contudo, como nota Robert Gay (comunicação pessoal), o acesso "informal" aos recursos públicos pode ser visto como ilegal em mais de um sentido. 
Lucina e sua comadre, Antonia, fabricam bonecos com uma máquina de costura que pertence ao Plano País. Esse programa estatal tentou desenvolver microempreendimentos em bairros pobres. O governo provincial distribuiu pequenos subsídios monetários entre diferentes grupos para a compra do maquinário necessário para produzirem alguma mercadoria, obtendo, assim, uma renda extra. A intenção original do programa era "fortalecer a organização comunitária". Em Cóspito, uma parte dos fundos foi capturada pelos mediadores, transformando-se em um recurso extra para seus círculos íntimos. ${ }^{12}$ Matilde obteve um desses subsídios e organizou um grupo de mulheres para trabalhar no Centro Cultural. Provê Lucina e sua comadre das matérias-primas para trabalhar; seu modo de produção artesanal não é suficientemente competitivo frente aos muito mais baratos bonecos importados. Como comentou comigo Lucina, "as importações acabaram conosco [...]. Mas ainda fazemos bonecos quando é preciso, como para o Dia das Crianças". Lucina considera-se amiga de Matilde: "Ela sempre te dá uma mão". Conhece Matilde desde 1984 e é uma das delegadas do Plano Vida. Matilde também ajuda Lucina com comida.

Ingrid ocupa agora o lugar deixado vago por Lucina como empregada doméstica de Matilde. Está encarregada de abrir e fechar o Centro Cultural e da distribuição dos medicamentos e dos pacotes de comida que Matilde traz da prefeitura. Também participa na organização dos atos junto com os dois filhos de Matilde (Pedro e Paco), distribuindo camisetas, cigarros e bebidas. Ingrid também é delegada de quarteirão do Plano Vida. Sua avó sofreu um ataque cardíaco recentemente. Matilde fornece a ela os remédios, extremamente caros e vitais.

A mãe de Ingrid me disse que estava esperando que Matilde conseguisse um posto na prefeitura para sua filha. A "expectativa de trabalho" funciona como um importante cimento dentro do círculo íntimo. Apesar de nem todos serem empregados na prefeitura, o fato de que algum/a consiga um trabalho por contrato ou de tempo parcial tem um "efeito de demonstração" importante. Se forem "pacientes", cedo ou tarde serão recompensados com um trabalho.

\footnotetext{
12 A coordenadora do Plano País, Analia Mat, concorda em que os punteros tentaram "pegar o programa". Por razões óbvias, não admite que, até certo ponto, tiveram sucesso. A escassa investigação realizada sobre programas sociais demonstra que Cóspito é uma área particularmente quente, na qual os punteros peronistas têm um impacto importante na implementação de programas sociais (Schapira, 1996).
} 
Mario obteve seu trabalho no centro de saúde local depois de participar na banda de Matilde "com os tambores". Após seis meses, Matilde ofereceu a ele o posto vacante. Agora assiste a todos e cada um dos atos nos quais participa Matilde. A mulher de Mario, Victoria, é uma das 23 delegadas do Plano Vida em Vila Paraíso.

O círculo de Matilde tem outros círculos em seu interior, como a rede de Cholo. Cholo "trabalha para Matilde [...], ela coordena o que eu tenho que fazer". Matilde manda para a UB de Cholo pacotes de comida e medicamentos para serem distribuídos entre "sua gente" na área próxima da Quinta Rua. Ele é "um puntero de Matilde”. É também funcionário fantasma, com um contrato na prefeitura que deve ser renovado com a explícita aprovação de Matilde. Ela também enviou a ele os canos para construir os esgotos e prometeu mandar umas máquinas niveladoras para alisar o terreno vazio localizado na frente da UB de Cholo. Ele quer construir um campo de futebol ali e, com isso, obter 150 pesos mensais pelo aluguel.

"Quando comecei a trabalhar com Matilde, ela me disse que a UB tinha que estar aberta todos os dias do ano [...]", diz Cholo; e Matilde deu a ele um recurso chave para começar: o primeiro telefone público da zona. As pessoas iam até "o Cholo" para usar o telefone, para buscar leite em pó, para pedir algum medicamento. Agora que a privatizada companhia telefônica instalou aparelhos em muitas casas da zona, o telefone público não é mais um recurso tão importante. Contudo, aqueles que ainda não têm telefone ou aqueles cujo serviço é cancelado por falta de pagamento, recorrem à "UB de Cholo". Ele distribui leite do Plano PROMIN, comida e remédios, e abre sua UB quase todos os dias do ano. Muitos vizinhos identificam a UB com a prefeitura: "Aí na esquina, na prefeitura".

Em palavras de Matilde, Cholo é "uma peça-chave do grupo". É bastante conhecido em "seu setor" e definido por muitos vizinhos como um dos que mais fizeram pelo melhoramento da vila. Cholo também trabalha para o Plano Vida. Todas as manhãs (exceto aos domingos), acompanha o caminhão do plano em seu percurso pelo interior da vila e por outros bairros e vilas vizinhas. Junto com outros dois homens, distribui o leite, os ovos e os cereais entre as delegadas. Também "passa a voz" sobre as novidades concernentes ao funcionamento do plano (um próximo ato a que assistirão o governador ou sua esposa, a distribuição do jornal do programa etc.), e sobre as novidades relativas ao $\mathrm{PJ}$ (o horário de encontro para um ato, o convite para um 
churrasco etc.). Informa ainda Mimí sobre qualquer problema que possa ter uma delegada de quarteirão (um novo membro do plano, uma queixa por falta de mercadoria etc.). Ele ganha 50 pesos semanais por esse trabalho.

Em termos de sua estrutura, o "círculo íntimo" de Pisutti é idêntico ao de Matilde. Contudo, o número de pessoas que têm um relacionamento "próximo e pessoal" com ele é bastante menor, seu "círculo íntimo" é mais estreito. Alfonsina obteve seu posto de trabalho em uma escola pública graças à intervenção de Pisutti; Rosa consegue os medicamentos para sua hemiplegia "graças a ele"; Marta, os remédios para seu pai, "por intermediação de Juancito". Como no caso do círculo íntimo de Matilde, esses "detentores de problemas" aprovisionam os "resolvedores de problemas", como Juan Pisutti, com alguns serviços. O "círculo íntimo" ajuda os mediadores na resolução cotidiana de problemas: são eles que coordenam os refeitórios que funcionam na UB, são os encarregados de abrir e fechar o local, são os que anunciam ao "círculo externo" quando está disponível o mediador na UB e os que distribuem a informação sobre a distribuição de mercadoria na UB e no edifício municipal. Diferentemente de Matilde, Juancito não tem outra UB trabalhando para ele. Sua área de influência, que é muito mais limitada que a de Matilde, cobre apenas as quatro quadras que cercam a UB. Spallina, um velho amigo de Juancito e morador de Vila Paraíso há muitos anos, é um daqueles que "passam a voz" no "círculo exterior". É uma espécie de "embaixador itinerante" da UB de Pisutti.

O "círculo exterior" - os potenciais beneficiários das capacidades distributivas do mediador- relaciona-se com os referentes por meio de "laços fracos". ${ }^{13}$ Entram em contato com ele quando surge algum problema ou quando precisam de algum tipo de favor (um pacote de comida, um medicamento, uma licença de conduzir, o caminhão da água, um amigo preso etc.); mas não desenvolvem laços de amizade ou parentesco fictício com os mediadores. Apesar de poderem assistir aos atos ou reuniões organizadas pelos mediadores, ou até mesmo votar por ela ou ele em alguma eleição interna, não têm um relacionamento íntimo, diário e próximo com ele ou ela. Em outras palavras, os laços que vinculam os mediadores com seu "círculo íntimo" são densos e intensos; os laços com o "círculo exterior" são mais ocasionais e intermitentemente ativados.

Sobre a diferença entre laços fracos e fortes (tempo, intimidade, intensidade emocional, etc.) ver Granovetter (1973). 
A base para essa relação "forte" é múltipla. Aqueles que fazem parte do círculo íntimo conhecem o mediador há um bom tempo (usualmente mais de quatro ou cinco anos), e os referentes já "deram uma mão" em situações de extrema necessidade. Os referentes "vieram ao resgate" sem segundas intenções. A partir desse "favor fundacional", uma relação de ajuda mútua foi desenvolvida. Parafraseando o Durkheim de A divisão do trabalho social, poderíamos dizer que os membros do círculo íntimo estão vinculados ao mediador "por laços que se estendem além do momento fugaz em que se realiza a transação" (Durkheim, 1984, p. 173). A "transação fundacional" transforma-se em laço, e esses laços concatenar-se-ão em redes.

\section{Controlando recursos e informação}

As redes de resolução de problemas não são estruturas congeladas, sem temporalidade. Também não são o resultado intencional da ação calculada, planejada e/ou cínica de um político. São o produto de interações regulares, as quais, embora normalmente inauguradas por um "favor fundacional", devem ser cultivadas e praticadas de maneira constante. Pode ser que Juancito, dada sua posição atual no jogo político local, não tenha muito acesso aos recursos distribuídos pela prefeitura. Mas precisa estar disponível para escutar e apoiar os membros de seu círculo. Faz isso pelo menos duas vezes por semana em suas reuniões na UB.

Como um professor universitário norte-americano, Juancito tem seus "horários de escritório" na UB. Ocupa as tardes das quartas-feiras e as manhãs dos sábados atendendo as pessoas que vão até a sua UB. Seu círculo íntimo está normalmente ali, preparando chimarrão, distribuindo leite em pó, conversando sobre fatos recentes. Juancito terá tempo de escutar cada um dos que se aproximam da UB. Quase todos vêm para pedir algo que está fora de seu alcance (trabalho); dará a eles um bônus para que busquem a mercadoria que é distribuída na prefeitura. Informa o dia exato da distribuição e a maneira em que devem proceder para obter "os nove quilos de mercadoria". Juancito também utiliza seus contatos no Hospital Evita ou sua própria obra social para conseguir medicamentos em caso de urgência.

Em uma das primeiras anotações em meu diário de campo (dezembro de 1995), estava extremamente surpreso pelas semelhanças entre uma UB e a sala de espera de um médico: 
Hoje foi meu primeiro dia na UB de Pisutti. Na prefeitura ele me disse que fosse encontrá-lo lá, porque o terceiro andar do município é "uma loucura para conversar". Após perguntar para alguns vizinhos se sabiam onde estava a UB (quase todos sabiam), entrei na UB. Estava muito ansioso, porque era a primeira vez em minha vida que entrava em um local do PJ.

Lá estavam dez pessoas conversando vivamente. O lugar estava repleto de fotos de Perón, Evita, Duhalde e Rolo Fontana. Bem na frente da entrada, Oscar anota os nomes de cada novo visitante. Mabel prepara chimarrão e oferece biscoitinhos. Alejandra e Alfonsina distribuem leite em pó (Plano Materno-Infantil). Estão posicionadas na frente de uma mesa que divide o local em dois. Atrás da mesa, uma grande cortina. $\mathrm{O}$ espaço atrás da cortina é “o escritório de Pisutti”. Ele está “atendendo" (verbo utilizado por Alejandra e Alfonsina quando perguntei por Juan). "Ele disse que eu viesse hoje”, comentei com elas (depois de dar meu nome para Oscar). "Ele está atendendo, tem cinco pessoas antes de você." Nesse momento, Dom Mario sai do escritório e escuto Juancito dizer: "Felicitações [...], me disseram que sua neta vai casar". Alfonsina também cumprimenta Dom Mario e diz: “O próximo”. Uma mulher com sua filha entram no "escritório".

Agora percebo de que estava estupidamente nervoso. Apesar de que já tinha me encontrado com ele na prefeitura, hoje devia explicitar em detalhe as razões da minha presença na vila [...]. Assim como muitos dos que estavam esperando por Juancito, eu também tinha "um problema para resolver": minha tese de doutorado. Será que Juancito (ou Matilde) me "permitirá” realizar meu trabalho de campo? Será que vão me ajudar?

Dentro da rede peronista de resolução de problemas, os mediadores funcionam como guarda-barreiras entre o fluxo de bens e serviços provenientes do poder municipal e o fluxo de apoio e votos que provém dos "clientes". Os recursos chegam da prefeitura para a UB, onde os mediadores têm poder discricional. A informação relativa à distribuição de alimentos no edifício municipal também circula por meio das unidades básicas. Como me dizia a proprietária de uma UB: “Todos os meses, nas reuniões do partido, o prefeito nos informa (as 140 unidades básicas que usualmente participam da reunião) sobre o dia em que vão dar comida [...]. Nós dizemos para os vizinhos". Sendo membros do Partido Justicialista, os mediadores têm as conexões que permitem que tenham acesso ao conhecimento sobre a distribuição de recursos. Usufruem do que os analistas de redes chamam "centralidade posicional".

Spallina e Cholo (membros dos círculos íntimos de Juancito e Matilde) são os agentes que passam a voz sobre quem tem a ajuda (e quem precisa 
dela). Apesar de que os vizinhos, em geral, sabem que a prefeitura distribui mercadoria, ignoram o dia exato em que será feita a distribuição. Mais do que isso, desconhecem os sempre variáveis procedimentos para obter as sacolas de mercadoria. Os mediadores sabem o dia e a hora, e têm as senhas sem as quais os vizinhos não podem retirar as sacolas. Desconheço se essa ignorância é "deliberadamente criada" ou se é uma ignorância que "simplesmente acontece" (Erickson, 1996). Contudo, como ilustra o seguinte episódio, existem algumas ocasiões nas quais os mediadores confundem as pessoas de maneira intencional, para efeitos de constituírem-se como canais de informação entre a vila e a prefeitura.

\begin{abstract}
No começo de agosto de 1996, Pisutti comunica-se com a coordenadora do refeitório infantil que funciona na igreja católica local (Norma). Apresenta-se como o funcionário municipal que é capaz de obter produtos lácteos e verduras para o melhor funcionamento dos refeitórios. A Secretaria de Ação Social não abastece os comedores com leite, queijo e verduras. Norma diz a ele que, normalmente, ela pergunta para Graciela (trabalhadora social na Secretaria de Ação Social) cada vez que o refeitório precisa de alguma coisa. Qualquer problema que temos, Norma diz a Pisutti, "nos contatamos com Graciela". Pisutti diz a Norma, "é exatamente a mesma coisa, pode contatar comigo ou com Graciela". A trabalhadora social estava indignada com esse episódio. Ela acredita que há muita "confusão" sobre o "lugar" que cada um (ela e Pisutti) deve ocupar.
\end{abstract}

Esse episódio ilustra o movimento típico dos punteros ou referentes peronistas em busca da própria essência da mediação: tentam constantemente transformar-se nos (únicos) canais que facilitam as transações e o fluxo de recursos (Gould e Fernández, 1989). O episódio também ilustra os obstáculos que devem enfrentar. Os trabalhadores sociais, organizações não governamentais e/ou dirigentes vicinais, erigem-se, em mais de uma oportunidade, em seus mais ferventes opositores. Seja essa ignorância dos beneficiários intencionalmente criada ou não, a verdade é que é estruturalmente induzida. Em um contexto de desertificação organizacional (no qual poucas organizações vicinais funcionam e no qual os moradores estão cada dia mais isolados entre si), existem poucas redes por meio das quais obter informação. Os referentes e seus círculos têm, pelo contrário, acesso a uma informação útil e, na maioria das vezes, vital. Na medida em que os moradores de Paraíso dependem do mediador para obter informação ou 
recursos materiais, podemos dizer que ele usufrui de "poder posicional" (Knoke, 1990, p. 10). Esse poder deriva "de redes de relações estruturais e existe à margem do conhecimento ou ignorância que os atores tenham sobre a estrutura de oportunidades mais abrangente na qual suas posições estão ancoradas" (Knoke, 1990, p. 10). Em outras palavras, o poder do mediador deriva de sua posição na rede, e da posição da própria rede na estrutura social da vila. Como mencionei, a rede peronista de resolução de problemas vem adquirindo crescente relevância, espalhando-se no território da vila como uma mancha de azeite na água.

Essas funções de "guarda-barreiras" e de "concentração da informação" são compartilhadas pelos diferentes tipos de mediadores que existem e existiram em diferentes momentos históricos e lugares geográficos. Os capitães de vizinhança, capituleros, cabos eleitorais, caudilhos ou punteros compartilham essas funções e essa localização estrutural. "Um mediador político pode obstruir ou facilitar o fluxo de demandas, favores, bens e serviços, desde ou para um grupo" (Carlos e Anderson, 1991, p. 172-173). Contudo, apesar de as funções dos mediadores serem as mesmas, existem diferenças significativas entre eles. Essas diferenças surgem do controle de recursos de cima (bens e serviços), o que determina, por sua vez, a quantidade de recursos de baixo (pessoas) que eles podem "controlar". Em outras palavras, os mediadores diferem quanto ao seu poder.

Quadro 1. Tipos de referentes e tipo ideal de trajetória

\begin{tabular}{c|c|c|c|c}
\hline potencial (Mimí) & $\begin{array}{c}\text { principiante (Cholo, } \\
\text { Andrea, Juana) }\end{array}$ & $\begin{array}{c}\text { consolidada } \\
\text { (Matilde) }\end{array}$ & $\begin{array}{c}\text { decadência } \\
\text { (Juanito) }\end{array}$ \\
\hline recursos de baixo & crescimento acelerado & crescimento moderado & $\begin{array}{c}\text { crescimento } \\
\text { acelerado }\end{array}$ & $\begin{array}{c}\text { deterioração } \\
\text { acelerada }\end{array}$ \\
\hline recursos de cima & crescimento moderado & estável & $\begin{array}{c}\text { crescimento } \\
\text { acelerado }\end{array}$ & $\begin{array}{c}\text { deterioração } \\
\text { moderada }\end{array}$ \\
\hline
\end{tabular}

Fonte: 0 autor.

\section{Transformando-se em mediador}

O fazer-se da ação (...) é o verdadeiro fazer-se do grande homem melanésio. É essencial estabelecer relações de lealdade e de obrigação de parte de uma quantidade de pessoal tal que sua produção possa ser mobilizada para a distribuição externa da 
produção de renome. Quanto maior a facção, maior o renome; uma vez que o impulso na distribuição externa tenha sido gerado o oposto também pode ser verdadeiro. Qualquer homem ambicioso que possa reunir seguidores pode se lançar em uma carreira social.

O fato de que em Vila Paraíso os cinco mediadores "realmente existentes" sejam do PJ, e que todos pertençam à linha interna do prefeito Rolo Fontana, não quer dizer que não competem entre si. É difícil encontrar a origem certa de suas rivalidades, mas podemos explorar o impacto que elas têm na rede de resolução de problemas.

Os mediadores podem competir entre si (Pisutti $v s$. Matilde), trabalharem um para o outro (Cholo para Matilde) ou simplesmente colaborar entre si (Andrea e Matilde). $\mathrm{O}$ fato de assistirem aos atos é um bom indicador dessas três possibilidades. Os seguidores de Pisutti jamais assistirão a um ato com Matilde (ou vice-versa). O círculo de Cholo irá se encontrar com os seguidores de Matilde antes do ato e assistirão juntos. Os seguidores daqueles mediadores que "colaboram" entre si estarão "livres" para assistirem com o referente que desejarem.

Nesse sentido, a assistência aos atos fornece informação sobre as responsabilidades que se têm com respeito a um mediador (e as responsabilidades deste para com seus seguidores). Em tanto tal, o ato é um "ritual", no sentido que Paige e Paige (1981) dão ao termo: uma oportunidade para declarar as intenções dos seguidores e dos mediadores e para avaliar as intenções de cada qual. Também é uma oportunidade para influir sobre os outros atores do jogo político local. O axioma pareceria ser: "Diz quanta gente mobilizas, e eu (o prefeito) direi quem és". Dessa maneira, os atos, como rituais e dramatizações, são "tentativas de persuadir outros, ponderar as intenções dos outros, medir a opinião pública e manipular percepções" (Paige e Paige, 1981, p. 261).

Em termos da resolução de problemas, os círculos concêntricos daqueles mediadores que colaboram (ou que pelo menos não competem) entre si sobrepõem-se parcialmente. Silvia, do círculo de Andrea, pode ir à UB de Matilde para pedir medicamentos ou comida.

Pelo contrário, quando os pontos centrais da rede competem entre si no campo político local - como Matilde e Juancito -, não existe superposição entre suas redes. Como Coca (parte do círculo íntimo de Pisutti) resume: "Se você vai pedir um favor para Matilde, não pode pedir para Juancito". 
Assim, as relações que os mediadores mantêm com seus seguidores cultivando-as continuamente - estão sempre mediadas e, de algum modo, determinadas pela relação que os mediadores mantêm com seus competidores no campo político local. Podem "atender" ou servir seus seguidores "na medida em que (e apenas na medida em que) também servem a si mesmos servindo outros" (Bourdieu, 1991, p. 183). Isso nos leva para uma dimensão não explorada da mediação política: os diferentes tipos de "mediadores realmente existentes". As práticas dos referentes peronistas incluem um repertório cultural, uma performance. Contudo, esta não é a única diferença que podemos encontrar. Apesar de sua localização estrutural ser similar (Gould e Fernández, 1989; Knoke, 1990), podemos detectar uma trajetória do mediador, que é fonte de diferenças no que se refere às suas capacidades. Vale a pena reconstruir essa trajetória para efeitos de não perder de vista essas diferenças internas, que são centrais em um mundo que parece homogêneo apenas de um ponto de vista externo e afastado.

A capacidade que os mediadores têm de "servir" seus círculos íntimos depende da "etapa" em que estão ou, o que vem a ser a mesma coisa, da posição na estrutura do jogo político local. Para expressá-lo de outro modo, a proximidade com o centro de poder (o prefeito) determina o melhor acesso aos seus recursos e, portanto, à (melhor ou pior) assistência aos seguidores. Quanto melhor é o serviço, "maior a facção", como diz Sahlins. ${ }^{14}$

As diferenças entre os referentes não são, então, apenas uma questão das relações entre si, mas do poder diferencial que possuem. Este poder coincide com a "etapa" em que estão suas carreiras e com o tamanho de seus círculos.

Pisutti costumava ser o "grande homem" de Paraíso. Foi secretário da Sociedade de Fomento da vila, escalou a hierarquia municipal até alcançar altas posições em política local. Foi secretário de Relações Institucionais: uma posição muito importante a nível municipal. Devido a causas que nem ele nem seus seguidores mais próximos explicitariam, o prefeito deslocou-o dessa posição e nomeou-o para uma nova - e politicamente irrelevante posição: assessor na área de ação social. Essa prática é bastante comum para

\footnotetext{
${ }^{4}$ As relações dos caciques urbanos no México com agentes supralocais (políticos e agentes de governo) também são fontes de poder essenciais. Como assinala Cornelius (1977, p. 341): "As relações do cacique com atores políticos externos são extremamente importantes para entender a influência que exercem na comunidade. O 'poder derivado' proveniente de fontes que estão fora do domínio do cacique pode ser efetivamente utilizado para consolidar sua posição dentro de uma comunidade e para desestimular disputas à sua autoridade".
} 
o "último caudilho" - como muitos se referem ao prefeito. Rolo Fontana costuma "jogar xadrez" com suas nomeações, e assim que alguém acumula uma exagerada parcela de poder pessoal, ele "corta sua cabeça". ${ }^{15}$

Pisutti ainda tem sua UB, que distribui recursos vindos do Plano MaternoInfantil, e reparte comida da Secretaria de Ação Social. Mas seu acesso aos recursos estatais foi drasticamente reduzido. Em suas próprias palavras: "Entende? Essas coisas da política [...]. Agora estamos fazendo o que podemos, tentando preservar a família”.

Vou concentrar-me no que Juan diz sobre a "preservação" de seu próprio grupo. Ao ter menor acesso a recursos desde cima, seus recursos desde baixo estão diminuindo. Para continuar sendo um referente, necessariamente precisa ter acesso a ambos. Como ilustra o último ato a que assistimos juntos, ele não vem obtendo muito sucesso na empresa: estava rodeado de apenas dez pessoas (diferente das 400 que Matilde "mobilizou"). Na pesquisa que realizei, seu nome ou UB foram raramente mencionados entre as "pessoas ou instituições que mais ajudam na vila”. Aqueles que o mencionaram moram a não mais de uma quadra da UB.

Juana Medina acabou de abrir uma UB na parte dianteira de sua casa. ${ }^{16}$ Pedele (vereador de um distrito próximo) está se transformando em outro "grande homem/nome" na parte sul da conurbação bonaerense. Está tentando penetrar no território de Cóspito com a intenção de transformar-se no próximo prefeito ou deputado provincial. Pedele está abrindo a maior quantidade de unidades básicas possíveis em bairros pobres e vilas, e Juana "entrou em contato com ele no lançamento da campanha de Menem” (1995).

Naquele momento, Juana acabara de perder seu trabalho como empregada doméstica e seu marido, o seu como operário da construção. Tinham acabado de abrir uma quitanda na parte dianteira da casa. "Mas, viu, abrimos a quitanda e as coisas não estavam saindo bem [...] então decidi abrir uma UB, e olha só o que aconteceu [...]." O que aconteceu é que sua decisão coincidiu com a carreira ascendente de Pedele. Agora ele paga a luz e o gás que Juana e sua família usam na UB e, por extensão, em sua casa.

5 "O velho é uma raposa"é a expressão que melhor reflete suas táticas. Foi mencionada repetidas vezes durante meu trabalho de campo.

${ }^{16}$ Apesar de que as unidades básicas são formalmente parte da burocracia do partido, na prática operam fora da organização formal do partido. Não estando registradas oficialmente, as unidades básicas podem ser abertas e fechadas sem qualquer tramitação legal. Sobre isto, ver Levitsky (1997, p. 15). 
Os recursos vindos de cima aos quais Juana tem acesso são limitados. Distribui leite em pó do Plano Materno-Infantil, mas não tem acesso direto à comida distribuída pelo município (apesar de ter acesso à informação relativa aos dias de distribuição, por meio de sua participação nas reuniões do Partido). Embora seu acesso aos recursos materiais seja limitado, "eu compenso isso com outras coisas", disse ela. Essas "outras coisas" incluem a organização de viagens para os meninos e meninas da vila. Pedele consegue dois ou três ônibus da Prefeitura de El Mirador e ela obtém pão e linguiças ou carne do anexo municipal. Uma vez por mês, leva quarenta crianças, aproximadamente, para alguma praia (Punta Lara) ou parque próximos. "Eles estão felizes", disse ela. "Com certeza”, respondi, "mas não é muito trabalho, conseguir os ônibus, a comida e encarregar-se dos meninos?”. Provavelmente sem perceber, revelou um dos segredos das práticas dos mediadores: "Não é tão difícil conseguir as coisas, precisa só saber puxar a linha certa, bater na porta certa. O mais importante é conhecer a pessoa indicada”.

No momento, Juana conhece a "pessoa indicada" (Pedele) e, se ele ascender no campo político local, ela certamente terá acesso a mais recursos. Se ela conseguir "mobilizar gente" para seu patrão político terá mais bens e mais informação. O que acaba de acontecer com ela provavelmente não tornará a ocorrer: "Viu [...] perdi o Plano Vida, mas tenho o Plano Materno".

"Perdi o Plano Vida, mas tenho o Plano Materno", e "mas, viu, abrimos a quitanda e as coisas não estavam saindo bem [...] então decidi abrir uma UB, e olha o que aconteceu [...]" estão longe de ser simples anedotas. Elas condensam os dois aspectos centrais da mediação política: a) depende, de forma significativa, dos recursos estatais; e b) oferece uma atraente passagem para a mobilidade social.

Os programas de assistência social são o "butim" que os mediadores tentam obter para efeitos de melhorar suas carreiras. Esses programas representam os "recursos desde cima" que precisam para resolver problemas e, portanto, para fazer política. A política significa "ter tua própria gente", tua própria facção. "Quanto maior é a facção, maior é o renome", como com o grande homem da Melanésia analisado por Sahlins. Quanto melhor for o acesso que se tenha aos recursos do Estado, maior será a capacidade de resolver problemas, e melhores serão as possibilidades de conseguir um cargo público (via eleições ou por nomeação). Novamente, Juana ilustra este ponto. Perguntei a ela se estava esperando um trabalho na prefeitura. É a única puntera sem um cargo público. 
Autor: Agora que está com Pedele, quem sabe vai conseguir alguma coisa na prefeitura $[\ldots]$

Juana: Não, ainda não, quem sabe em 99.

Andrea oferece outra "interação anedótica” por meio da qual podemos compreender a particular maneira de fazer política dos punteros. Estávamos em sua casa, enquanto esperava um jovem que vinha buscar uma carta do prefeito. Esse jovem tinha um amigo que recentemente falecera de AIDS e não tinham dinheiro para o funeral. Havia recorrido a Andrea e ela conseguiu uma carta do prefeito na qual pedia à funerária local que eximisse esse jovem do pagamento. Em outra ocasião, ela mencionou esse fato como exemplo de sua "maneira de fazer as coisas". Estávamos em sua UB, localizada no centro de Vila Paraíso, enquanto ela me mostrava uma pesquisa que uma ONG tinha realizado anos atrás na vila. "Eles queriam melhorar as condições de vida da vila [...], mas queriam mobilizar as pessoas [...]. Essa não é a maneira como eu faço as coisas, eu prefiro resolver pequenos problemas, como o funeral, em vez de mobilizar tanta gente e criar falsas expectativas [...]. Eu prefiro fazer trabalhos menores, como poder dar um remédio no meio da noite." Em outras palavras, para os pobres, soluções pequenas (e pobres) para seus problemas, respostas simples, mas personalizadas. Essa parece ser a "sua maneira".

Mimí e Matilde ilustram outros elementos dos tipos e trajetória dos mediadores políticos. Não apenas são parentes mas também encarnam, de maneira ideal-típica, a potencialidade de transformar-se em referente (Mimí) e a forma de um referente vicinal no topo de sua carreira (Matilde).

\section{O Plano Vida}

Para o Plano Vida, organizamos uma reunião na igreja e chamamos as pessoas da comunidade, pessoas que estavam trabalhando com a igreja, vizinhos que estavam interessados neste novo programa social. As delegadas de quarteirão surgiram dessa reunião (Mimí, coordenadora do Plano Vida em Vila Paraíso).

A primeira reunião do Plano Vida foi organizada aqui, na igreja. Estava cheio de gente ligada a Matilde e Cholo, queriam controlar a coisa. Eu não sou bobo [...], estive dez anos em uma unidade básica e sei que nesse plano é tudo uma questão de manipulação de gente (Toni, zelador da igreja católica). 
Inspirado no Plano de Alimentação Complementar chileno e no funcionamento dos Comitês de Defesa da Revolução cubanos, o Plano Vida (PV) é o maior programa de distribuição de alimentos que desenvolve o governo da província de Buenos Aires. Projeto concebido pela esposa do governador, Hilda de Duhalde, o PV foi lançado em um dos distritos mais pobres da conurbação, em 1994. De acordo com números oficiais (novembro de 1996), o PV atinge 38 distritos bonaerenses e cobre 644 bairros. É financiado com recursos estatais provenientes do Conselho Provincial da Família e Desenvolvimento Humano, presidido por "Chiche" Duhalde, que também é presidenta do ramo feminino do PJ.

O PV distribui leite, cereais e ovos para mais de meio milhão de meninos e meninas entre o primeiro e o sexto ano de vida e para mulheres grávidas. Essas crianças e mães moram em áreas que o "Mapa da pobreza"17 define como áreas de "necessidades básicas insatisfeitas". A distribuição diária de leite e a semanal de cereais e ovos são feitas pelas delegadas. Elas não recebem pagamento monetário algum por seu trabalho, apenas o meio litro de leite diário e a ração de ovos e cereais semanais que recebe o resto dos "beneficiários". Como tantos outros programas de alimentação suplementar na América Latina, o PV exemplifica a "carga desigual" que devem suportar as mulheres na não remunerada manutenção e reprodução dos recursos humanos. Como assinala Elson (1992, p. 26), "no contexto de crise econômica e ajuste estrutural, as mulheres são particularmente valorizadas por sua habilidade para projetar e implementar estratégias de sobrevivência para suas famílias, utilizando seu trabalho não pago para absorver os efeitos adversos das políticas de ajuste estrutural".

Em palavras de um dos poucos jornalistas que prestam atenção a esse programa, as delegadas representam "um exército de 10.000 mulheres trabalhando de graça no maior plano social da Argentina" (Página 12, 30 de agosto de 1996, p. 8). Em novembro de 1996, as delegadas, que de acordo com a definição oficial "dão vida ao Vida", chegavam a 13.000.

O PV tem um coordenador distrital que está empregado na Secretaria de Ação Social da respectiva prefeitura. Cada coordenador distrital está encarregado de um número variável de coordenadores de área. Mimí está encarregada de Vila Paraíso, coordenando o trabalho diário das 23 delegadas de quarteirão da vila.

17 Informe produzido pela CEPAL e pela UNICEF sobre a pobreza na América Latina (NRT). 
Chiche Duhalde também dirige o programa de refeitórios infantis. Esse programa foi designado para equipar refeitórios de bairro e para aprovisionálos semanalmente com a quantidade necessária de comida para crianças e famílias de "bairros carentes". Esses refeitórios infantis também são financiados pelo Conselho da Família e Desenvolvimento Humano, e são coordenados em nível distrital por um funcionário da Secretaria de Ação Social. Em Cóspito, os refeitórios são coordenados por Susana Gutiérrez, assessora do prefeito Rolo Fontana. Susana é uma "mediadora consolidada" em outro bairro de Cóspito.

Nesta seção vou me concentrar no marco discursivo do PV e do programa de refeitórios infantis, prestando particular atenção às palavras de sua diretora, a esposa do governador, e às dos funcionários que incansavelmente fazem sua propaganda. O elemento chave nessa retórica é o suposto caráter apolítico desses programas. Depois, contrastarei esse elemento retórico com o que ocorre "no terreno", no funcionamento diário de ambos os programas.

O ponto de vista oficial, isto é, "o ponto de vista dos funcionários, expressado no discurso oficial” (Bourdieu, 1990, p. 136) tem que ser tomado seriamente em consideração na medida em que constitui uma característica distintiva do Estado como entidade que possui o monopólio da violência simbólica. Contudo, o repertório discursivo das elites estatais é uma construção dialógica. Na última parte desta seção, analisarei o "outro lado" do ponto de vista oficial. Vou examinar as avaliações que as delegadas e algumas "beneficiárias" de Paraíso fazem do PV. A suposta falta de favoritismo partidário será contrastada com minhas próprias visões sobre o funcionamento de ambos os programas e com os (diferentes) pontos de vista das delegadas. Embora não exista uma manipulação política direta, vou argumentar que o efeito real da retórica oficial é muito mais sutil: os programas são personalizados na figura do governador e de sua esposa. Em palavras de um dos beneficiários do PV: "Menem não tem nada a ver com o plano. Isto não é uma coisa de partido político [...], isto é de Chiche"18.

${ }^{8}$ Esta seção está baseada na leitura anual dos principais jornais da conurbação de grande favoritismo político pelo governador Duhalde, o que oferece uma fonte inigualável para analisar o ponto de vista oficial. Durante o segundo semestre de 1996, a esposa do governador apareceu nas páginas desse jornal pelo menos uma vez a cada duas semanas. Em entrevistas ou nos recorrentes "lançamentos" do $\mathrm{PV}$, as palavras de Chiche foram quase sempre as mesmas, pelo que evitarei uma exposição semanal detalhada. Em compensação, vou me concentrar nos pontos mais importantes do seu discurso. A última parte desta seção está baseada em minhas entrevistas em profundidade com as 23 delega- 


\section{"Isto não tem nada a ver com política". O ponto de vista oficial}

Sempre iniciados com grande fanfarra e propaganda, os atos de lançamento do PV constituem uma das ocasiões em que Chiche se encontra pessoalmente com as delegadas. Em seus discursos, sempre insiste sobre dois pontos fundamentais: a) o programa tem que ser entendido como uma expressão do esforço, solidariedade e amor das delegadas por seus vizinhos “carentes", e b) o programa não deve ser contaminado pela política.

Chiche sempre acentua os sacrifícios realizados pelas delegadas "em sua luta diária pelo sucesso do programa". De acordo com ela, o PV é uma experiência quase única na América Latina: não existem precedentes de uma organização de mulheres tão forte que desenvolva um programa estatal. Esse programa confia principalmente nas mães, que, "como sentem tanto amor por seus filhos, são capazes de implementar o programa de maneira desinteressada". Chiche também enfatiza o "misticismo" com que as delegadas expressam a solidariedade para com seus vizinhos.

A "ajuda social" para os pobres é invariavelmente feminizada: as mulheres, de acordo com Chiche, têm muito mais criatividade que os homens para fazer "trabalho social". Solidariedade, amor, afeto e verdadeira vocação são as forças (femininas) que, de acordo com a apresentação pública de Chiche e de funcionários próximos a ela ou ao programa, animam o programa.

Um dia típico de uma delegada em Paraíso começa em torno das cinco da manhã, quando o caminhão do PV descarrega os sacos de leite e os ovos. Cada delegada distribuirá depois (normalmente entre as oito da manhã e o meio dia) a ração diária a uma quantidade designada de crianças e mulheres grávidas (em Paraíso, a quantidade de beneficiários por delegada varia entre 39 e 170). Esse trabalho é realmente cansativo, "mas vale a pena o esforço", afirma Chiche. "Vale a pena o esforço", porque Chiche e as delegadas fazem "tudo por amor". ${ }^{19}$

Como se fosse necessário selar o trabalho árduo (e não remunerado) das delegadas com simbolismo poético, funcionários peronistas associam

das de quarteirão do PV em Paraíso. Também está baseada em minhas observações diárias sobre o funcionamento de ambos os programas e na minha participação em vários atos de "lançamento" do PV e dos refeitórios infantis.

19 "Tudo por amor" é o título de uma entrevista feita com Chiche e publicada no primeiro número da revista do PJ da Província de Buenos Aires. O título é suficientemente ambíguo, porque não explicita de quem vem esse amor: é o amor das delegadas de quarteirão pelas suas beneficiárias ou o de Chiche pelas "suas" delegadas? 
seu trabalho com o de Eva Perón. Em um artigo que vale a pena citar, uma vereadora peronista, em um supremo ato de condescendência, assinala:

As delegadas não estão nas páginas das revistas, mas são belas mulheres que dão um novo impulso à ação social [...]. São as autênticas herdeiras de Evita: levam a voz de Eva em cada uma de suas palavras e os olhos de Eva em cada um de seus olhares. Elas sabem que o caminho para a justiça social se conquista com generosidade; uma generosidade típica daquelas que estão dispostas a deixarem sua alma por uma vida mais digna.

A celebração populista do esforço dessas "humildes mulheres", e a personalização do programa na figura do governador, é vista claramente nas palavras do ministro da Saúde. Sem especificar quem está acusando, sustenta que "querem nos fazer acreditar que as mulheres bem-sucedidas são aquelas que têm corpos perfeitos, querem nos fazer acreditar que temos que imitá-las. Mas as mulheres realmente bem-sucedidas são nossas mulheres gordinhas, morenas e baixinhas, que trabalham para que outros tenham sua comida diária [...]. Vocês são as mulheres de Duhalde [...]. Vocês, as Martas, Juanas, Marías, Josefas serão as mulheres de Duhalde que levarão o Plano Vida para os bairros".

Embora surpreendentes por seu sexismo condescendente, essas palavras não são pouco comuns. São repetidas uma e outra vez nos quase semanais atos de lançamento do PV, nas doações que Chiche realiza aos refeitórios infantis (fornos, geladeiras etc.), na inauguração de outros programas sociais (Plano Bairros Bonaerenses, Plano Documentário Eva Perón).

O "ponto de vista oficial" dos programas de assistência insiste na falta de favoritismo partidário ou de manipulação. Como se quisesse exorcizar esses programas dos malvados espíritos da política, Chiche exorta publicamente as delegadas para que se abstenham de qualquer atividade política: "Não deixem que ninguém do nosso partido ou de qualquer outro partido politize o programa, porque, se isso acontecer, o sentido profundo do PV irá se perder [...] ninguém deve usá-las". A política não deve nunca "infectar" o programa, a política deve ser uma atividade alheia às delegadas. Elas devem fazer "ação social", nós (os políticos) fazemos política. Assim, a atividade política é definida como uma ação estranha às preocupações cotidianas. Defendendo o plano da contaminação política, a atividade política é isolada e definida 
como uma tarefa para os políticos. Como afirma Chiche, "não pedimos que vocês pensem em termos políticos como fazemos nós, mas que pensem nas crianças dos bairros nos quais vocês moram e que pensem que seu trabalho pode salvar muitas vidas".

Embora Chiche Duhalde critique constantemente aqueles que privam de comida "os que não compartilham sua ideologia política", nunca menciona ninguém de seu partido ou de outro partido. "Não podemos fazer política com isto (PV) porque estão em jogo aqueles que mais amamos." Isso implica que, sim, existem aqueles que fazem política com o programa. Contudo, Chiche nunca se referirá explicitamente às pessoas que, em suas palavras, "tiram proveito das delegadas". Suas reprimendas e advertências públicas ("eu peço por favor a vocês: não troquem uma sacola de comida por uma filiação ao partido e denunciem aqueles que fazem isso [...], não deixem que isto continue") são mais do que uma simples caça às bruxas. Por um lado, contêm um elemento de verdade: como veremos, o Partido Justicialista utiliza esses e tantos outros programas para fins políticos. Por outro lado, ao apresentar-se como juiz imparcial, Chiche Duhalde surge como única garantia das intenções originais ("sociais") desses programas.

Provavelmente não existe ocasião melhor para analisar as intenções de imparcialidade política que as declarações que Chiche e os coordenadores distritais do programa realizam quando inauguram o PV em um novo bairro. Para mim, a pergunta mais óbvia é: como recrutam as delegadas? A versão oficial acentua a participação desinteressada da comunidade na seleção das delegadas. Como disse Mimí, em Paraíso, "para o Plano Vida, organizamos uma reunião na igreja e chamamos o pessoal da comunidade, pessoas que estavam trabalhando com a igreja, vizinhos que estavam interessados neste novo programa social. As delegadas surgiram dessa reunião". Em um nível mais geral, Chiche contará invariavelmente a mesma história: "Para evitar a politização do $\mathrm{PV}$, confiamos nas instituições da comunidade, a igreja, a escola, a sociedade de fomento, o centro de saúde. Fazemos isso para escolher um tipo específico de trabalhador social solidário. Esse tipo de mulher vai defender o programa sem estar sujeita a flutuações políticas". Em outra entrevista, ela garante que "quando começamos a organizar o trabalho social em um novo bairro buscamos o apoio da comunidade e das suas organizações. Eu tento dar participação às pessoas; recorro à igreja, à escola, à sociedade de fomento". Rejeita taxativamente qualquer fusão entre política partidária e 
programas de assistência social. Utilizando explicitamente o termo punteros (mas, novamente, sem dar nome a nenhum em particular), sustenta que os recursos estatais devem ser canalizados por meio das municipalidades e das instituições intermediárias reconhecidas.

Apesar de o discurso oficial negar isso constantemente, o PV e o programa de refeitórios infantis estão "politicamente contaminados". Como muitos outros programas de desenvolvimento comunitário no subcontinente, estes "oferecem aos governos um meio fundamental para [...] o exercício de controle" (Ward e Chant apus Graham, 1991). A manipulação política não é tão explícita como em outros contextos, mas não é preciso ser detetive para perceber como os interesses partidários abundam nesses programas.

Em novembro de 1996, Chiche veio até Cóspito para doar fornos, refrigeradores e panelas para os quarenta refeitórios financiados pelo Estado provincial. Enquanto aproximadamente 500 pessoas esperavam "a senhora" nervosamente, apresentaram-me Rosa, a encarregada do refeitório União e Lealdade e secretária da Unidade Básica de mesmo nome. Inocentemente perguntei a ela se era secretária do refeitório ou da UB. "É a mesma coisa", respondeu, e acrescentou que a sociedade de fomento funciona no mesmo lugar. Embora a coordenadora dos refeitórios a nível municipal, Susana Gutiérrez, constantemente enfatize que os refeitórios estão localizados em casas particulares ou no edifício da sociedade de fomento, em Cóspito 33 dos quarenta refeitórios funcionam em unidades básicas ou na casa privada dos punteros. Apesar de a coordenadora distrital do PV, Mimí, assinalar que as delegadas surgiram "naturalmente" da comunidade, vinte de 23 delegadas de Paraíso foram recrutadas pelos punteros peronistas. Quase dois terços dessas 23 são delegadas porque Matilde ou, o que vem a ser quase a mesma coisa, Cholo "convidaram-nas" a que fizessem parte do PV. A maioria das reuniões que Mimí tem com as delegadas de Paraíso são realizadas na UB de Matilde.

Tudo isso deveria ser suficiente para demonstrar a falsidade da "imparcialidade política" que Chiche e os funcionários municipais dizem defender. Contudo, quero concentrar-me nos efeitos reais da retórica oficial. Ao destacar o "amor" que une o esforço das delegadas e a incessante atividade de Chiche, e ao insistir na "imparcialidade política", o ponto de vista oficial constrói uma imagem do casal governante como sendo a única garantia de sucesso desses programas. Em outras palavras, o discurso oficial apresenta os programas como empresas pessoais dos Duhalde. No bairro, as coordenadoras 
de área são as que fazem a mediação dos esforços do governador e sua esposa. Dado que essas coordenadoras estão em contato diário com as delegadas, ser as intermediárias do PV constitui uma fonte (potencial) de poder político. O que Juana me disse ("Perdi o PV, mas tenho o Plano Materno") adquire, assim, um significado mais completo: o PV é um butim de "recursos desde cima" (estatais) extremamente útil para acumular "recursos desde baixo" (gente) e, assim, iniciar uma carreira como mediador político.

A partir daqui concentrarei minha atenção nas delegadas de quarteirão, para efeitos de examinar a maneira em que o discurso oficial se filtra para baixo e é entendido por elas. O que dizem as delegadas do que os funcionários dizem de elas? Tem algum efeito a personalização do PV nas figuras do governador e sua esposa? Existe alguma resistência ou oposição à associação entre os Duhalde e os programas sociais?

\section{Olhares a partir de baixo}

No momento em que escrevo este trabalho, o PV tem distribuído leite, ovos e cereais durante mais de um ano em Vila Paraíso, atingindo mais de 3.000 meninas, meninos e mulheres grávidas. O que chama imediatamente a atenção em todas e cada uma das entrevistas é que as delegadas destacam o bom funcionamento do PV. Em um mundo social degradado, violento e cheio de riscos, o PV introduz certeza: invariavelmente "o caminhão do Vida" vem todos os dias. Quase todas as delegadas contrapõem o PV à situação econômica atual: "Pelo menos, sabemos que vamos receber leite todos os dias" (Marta); "Não é muito, mas é uma ajuda" (Adela); "É uma ajuda real” (Rosita); "Com o PV não dá para sobreviver, mas é alguma coisa. É uma ajuda" (Manuela). Os beneficiários do PV concordam: "O PV é muito bom, porque te ajuda a economizar. Agora a gente sabe que não precisa comprar o arroz".

A ajuda "quem envia é Chiche". Ela não é como outros políticos que fazem promessas e nunca realizam nada; pelo contrário, "ela realmente cumpre". Adela e Manuela são as que melhor sintetizam as percepções e as sensações que a maioria das delegadas tem para com Chiche: "Eu estou muito agradecida a ela, porque realmente ajuda as pessoas", "Eu gosto da sua humildade. Ela trata muito bem as pessoas, é muito simples. Dá para confiar nela porque é muito humilde".

Em dezembro de 1995, o PV foi iniciado em Paraíso e zonas próximas, com um ato inaugural no Clube Social Vila Bosutti. A maioria das delegadas 
se lembra desse ato como uma "experiência emocionante". É importante citar suas respostas à minha pergunta ("O que você mais lembra daquele ato?), porque dão conta da personalização do PV na figura da esposa do governador:

Eu lembro que a esposa de Duhalde falou para nós e que foi muito carinhosa. Explicou o que tínhamos que fazer e disse que fazíamos isso por nossos vizinhos. Foi muito lindo [...], eu realmente gostei do que ela disse. Ela é uma mulher que expressa carinho quando fala, a maneira como fala (Victoria).

Foi muito lindo, muito emocionante. Só de pensar que esta mulher viria, que tem tão boas ideias. É tão bom. Porque ela veio aqui [...], a mulher de Duhalde, entende? $\mathrm{O}$ trabalho que ela faz é muito importante, porque ninguém imaginou uma coisa assim. Eu gostei muito do que ela disse. Ela falou para gente como eu [e nos disse] que tínhamos que trabalhar muito, sem abandonar (Marta).

Foi realmente emocionante conhecer Chiche, porque eu só tinha visto ela na TV ou nos jornais, mas nunca tinha estado tão perto. Acho que é uma pessoa cheia de carinho [...], é muito acessível, não diz "Eu estou em cima, e olho todo o mundo para baixo" (Aurelia).

Eu quase chorei quando ouvi a mulher de Duhalde no dia do ato, vi muito amor nela. Ela realmente gosta do povo, foi muito emocionante (Mabel).

Amalia também lembra o ato como uma "linda experiência”. Ela, Aurelia e algumas outras também lembram os distintivos que as identificavam como delegadas de quarteirão como algo que fez com que se sentissem orgulhosas: "Ter a credencial de delegada foi muito emocionante, foi uma espécie de distinção". Outras lembram a rosa que as funcionárias deram a elas como forma de felicitação.

Somente uma perspectiva que combine preconceitos de classe com desconhecimento poderia entender essas avaliações como resultado dos "valores tradicionais de dependência" que supostamente permeiam a vida popular e que as delegadas estariam reproduzindo. Pelo contrário, essas avaliações devem ser contextualizadas no marco histórico político-econômico (delineado nos dois primeiros capítulos de La política de los pobres). O que essas vozes estão nos dizendo deve ser posto no marco do sentimento generalizado de abandono, isolamento social e alto risco que impregna a vida na vila. Nes- 
se contexto, a distribuição diária de leite, cereais e ovos, uma palavra que dê conta de verdadeira "preocupação pelo outro", uma credencial ou uma flor fazem uma diferença: demonstram que alguém, "pelo menos alguém", preocupa-se pessoalmente por elas, que não estão "abandonadas".

O PV é uma rede de resolução de problemas em constituição. Muitas delegadas mencionam que os vizinhos, a partir da inauguração do programa, estão mais "conectados". Para Adela, o PV formou uma espécie de "corrente, e essa corrente está crescendo. Quando sabemos que algo está acontecendo, alguém faz correr a voz". Nessa rede, todas as rotas levam a Mimí, a coordenadora do PV em Paraíso.

Autor: O que faz quando as pessoas vêm com um problema?

Delegada: Vou buscar Mimí, urgente. Ela sempre diz que estou louca, porque sempre estou tentando encontrar a pessoa indicada para resolver isto ou aquilo. Tem muita gente que não sabe como se arranjar [...].

Apesar das vozes oficiais que dizem o contrário, a rede do PV está se superpondo cada vez mais à rede peronista. Não apenas a maioria das delegadas é recrutada pela via do partido e a maioria das reuniões é realizada na UB, mas o PV também é utilizado pelos punteros locais. Não é preciso ser um analista de redes para perceber que a "grande mulher" de Paraíso, Matilde, e a coordenadora do PV estão "conectadas": Mimí é sua irmã. Todas e cada uma das delegadas sabem disto e do que esse vínculo representa potencialmente em termos de resolução de problemas. Provavelmente é a delegada Cristina quem melhor sintetiza o uso político do programa e a crescente superposição entre ambas as redes. Contava que Matilde às vezes distribui comida em sua UB, e perguntei a ela:

Autor: Matilde pede alguma coisa a vocês em troca da comida que dá?

Cristina: Não, quando são feitos atos, Matilde nos convida. Agora que estamos no Vida, ela nos convida. Se é muito longe, ela manda um ônibus [...]. Nós estamos encarregadas de convidar o povo que está no PV, e levamos a quantidade de gente que podemos.

Em toda a sua franqueza, Adela e sua filha, Marcela, também sintetizam essa superposição de redes e a maneira em que a "troca" vai e vem sem palavras. Estava perguntando a elas sobre sua participação no PV: 
Autor: E como começaram com o plano? Porque parece muito trabalho... Adela: Matilde!!! (sorrindo). Mimí disse para a minha outra filha (a que conseguiu seu trabalho por meio de Matilde): "Luisa, você e sua irmã são as delegadas".

Autor: Vocês conheciam Mimí antes?

Marcela: Sim, porque temos uma boa relação com Matilde, com Mimí, com todos [...].

Adela: (rindo) Ela nem nos perguntou [...] só disse: "Vocês vão fazer isto [...]" Marcela: E não conseguimos dizer que não.

Adela: Então, fomos delegadas.

Autor: Por que não puderam dizer que não?

Adela: Porque temos uma boa amizade [...]

Marcela: Depois de um tempo, começamos a gostar (os itálicos são meus).

Apesar de terem sido recrutadas para o PV por mediadores políticos e de as reuniões serem, muito frequentemente, organizadas na UB, a maioria das delegadas rejeita enfaticamente o caráter político do programa. "Isso não tem nada a ver com a política”, concordam elas. E coincidem em dar todo o crédito pelo PV a Chiche e seu marido. Contudo, é importante explorar as vozes dissidentes.

Depois de contar que "quase chorou" no ato inaugural do PV, Mabel acrescenta que "Chiche pode até ter um montão de amor para dar; o problema é que tem que delegar responsabilidades". E continua: "Sejamos sinceros [...], há política no PV. Mesmo que a mulher de Duhalde diga que não há política [...] o programa está controlado pela política. Há gente das unidades básicas, a maioria das delegadas está no plano porque tem algum conhecido na política [...]". Toni, o zelador da igreja, concorda: "A primeira reunião do Plano Vida foi organizada aqui, na igreja. Estava cheio de gente ligada a Matilde e Cholo, queriam controlar a coisa. Eu não sou bobo [...], estive dez anos em uma unidade básica e sei que esse plano todo é uma questão de manipulação de gente". Alicia, outra delegada, também reconhece os aspectos políticos do PV: “Quem realmente se beneficia com o PV é quem está lá em cima, e diz: 'Eu juntei esta quantidade de delegadas'. Nunca dizem 'Este é o pessoal que trabalha para o PV'. Mas dizem: 'Este aqui tem tantas delegadas', e aparece como a primeira figura [...]. É uma pena, mas é assim [...], a política sempre foi assim. Se não fosse assim, estaríamos muito melhor”. Para Alicia, as flores, as credenciais e os diplomas que receberam das funcionárias não são suficientes: "Com as flores não posso cozinhar". 
Essas vozes dissidentes são uma minoria e, coincidentemente, vêm daquelas delegadas que não fazem parte dos círculos íntimos dos mediadores.

As implicações políticas do PV podem ser também analisadas a partir de outra perspectiva. Na população de Paraíso, 38\% dizem que votariam em Duhalde se as eleições fossem hoje. Das 23 delegadas, 21 votariam em Duhalde. A maioria concorda com Silvia: "Realmente gosto de Duhalde [...] como pessoa e como governador. Nunca tivemos ninguém como ele. Ninguém fez o que ele faz. Nunca vimos nada parecido com este programa, recebemos o leite todos os dias, e nunca chegam tarde [...]. Realmente, eu confio neles". Ser beneficiário do PV também faz uma diferença na hora de votar: entre aqueles que estão recebendo recursos do PV (38,5\% dos pesquisados), 54\% votariam por um candidato peronista.

Assim, o PV não é somente um efetivo programa de distribuição de alimentos. É uma rede de resolução de problemas que reforça diariamente as aspirações políticas do governador e da sua esposa por meio de uma extrema personalização dos benefícios materiais e simbólicos. É, além disso, uma rede que, contra o que argumenta o discurso oficial, não debilita, mas, pelo contrário, reforça as redes políticas peronistas. Conferindo a coordenação do PV à irmã da "Grande Mulher", o programa fortalece uma tendência preexistente na estrutura de oportunidades de resolução de problemas em Paraíso: de maneira crescente, todas as rotas para resolver problemas de sobrevivência levam ao grupo de Matilde.

\section{Dominação por constelação de interesses}

Para concluir, gostaria voltar às palavras de Matilde citadas no início deste texto: "Nós temos um costume: trabalhamos como uma família, para a família e com a família" e "Viu? Depois de tudo o que você viu [...] os votinhos vêm, não preciso ir buscá-los [...], os votos vêm sozinhos". Juntas, ambas as frases encapsulam boa parte da maneira de fazer política por meio da negação da política que os mediadores realizam.

\section{Uma família}

Certamente sem querer, Matilde dirige nossa atenção para a característica central de sua rede (e de tantas outras). Como em mais de uma oportunidade notaram autoras feministas, as famílias são sistemas econômicos, lugares de "trabalho, troca, cálculo, distribuição e exploração" (Fraser, 1989, p. 120). A 
"família" da rede é um lugar de relações de poder, e as redes dos mediadores são, sem dúvida, "redes de dominação" (Knoke, 1990).

A noção weberiana de "dominação em virtude de constelação de interesses" (Weber, 1968, p. 943) captura o tipo de relação que predomina na rede. Em particular, a noção de "dominação em virtude da posição de monopólio" parece projetada para entender o efeito das redes de resolução de problemas e, nelas, a relevância das práticas dos mediadores. De acordo com Weber, esse tipo de dominação está "baseada na influência derivada exclusivamente da posse de bens e habilidades vendíveis garantidas de alguma forma e atuadas sobre a conduta daqueles dominados, aqueles que permanecem formalmente livres e estão motivados simplesmente pela persecução de seus próprios interesses" (Weber, 1968, p. 943).

Dada sua posição monopólica no mercado de capitais, uma instituição bancária ou financeira grande pode impor seus próprios termos, em seus próprios interesses, na concessão de um crédito, exercendo, assim, uma “influência dominadora" no mercado de capitais. "Os devedores potenciais, se realmente precisam do crédito, devem, em seu próprio interesse, submeter-se a estas condições [...]. Os bancos de crédito [...] simplesmente procuram o seu próprio interesse e realizam-no melhor quando as pessoas dominadas, agindo em liberdade formal, perseguem racionalmente seus próprios interesses ao estarem forçadas nessa direção pelas circunstâncias objetivas" (Weber, 1968, p. 943). Sob esse tipo de dominação, o dominante não dirige diretamente a ação do grupo dominado; ao perseguir seus próprios interesses, o dominante (neste caso, o banqueiro monopolista) tem a capacidade de limitar as possibilidades que são abertas para o dominado (neste caso, quem precisa de créditos).$^{20}$

O Partido Justicialista em Paraíso tem posição similar a uma grande instituição bancária. Os mediadores seguem suas próprias carreiras políticas, tentam acumular a maior quantidade de poder político que podem e de melhorar as posições no campo político local. Ao acumularem recursos e informação vital para resolver problemas, transformam-se em "resolvedores de problemas". Não tentam dirigir diretamente as ações das pessoas carentes que precisam de recursos (o que Weber denominaria "dominação em virtude da autoridade, isto é, poder de dar ordens e dever de obedecer”). Contudo,

20 Para uma análise elaborada deste tipo de dominação, ver também Murphy (1988). 
somente uma abordagem que se centre em indivíduos em vez de relações pode deixar de ver os efeitos estruturais de dominação que estão envolvidos na posição dos mediadores peronistas. Ao buscarem a realização de seus interesses, alguns se transformam em quase monopólios na resolução de problemas. Ao fazê-lo, aumentam sua capacidade de limitar as possibilidades dos "detentores de problemas".

As relações que os mediadores estabelecem com seus respectivos círculos íntimos oferecem outra perspectiva complementar no que se refere à maneira como se realiza a dominação. Ao prover de informação e recursos que captam o interesse de seus seguidores mais próximos, a adesão voluntária é garantida a baixo custo. O poder é, nesse caso, econômico. E, por sua vez, os "detentores de problemas", embora seja verdade que resolvem seus problemas mais imediatos, vão ficando presos na rede peronista.

\section{Esperando votos}

Como Matilde dá a entender, os mediadores fazem favores e estão em permanente contato com os moradores da vila para efeitos de gerar apoio político. Assim como os membros da máquina política de Chicago, Estados Unidos, estudada por Guterbock (1980), os mediadores peronistas acreditam no modelo de troca (bens e favores por apoio político). A maioria das suas ações - fazer favores, transmitir informação, tentar "preservar a família”- está guiada por essa crença. Como afirma Guterbock, "o modelo de troca material" explica o apoio à máquina política nos seguintes termos: os membros do partido criam uma rede de obrigações por meio de seus serviços, diz-se que o povo paga essas obrigações votando em quem dizem que devem votar. Nesse modelo, a relação votante-mediador é "face a face, mas essencialmente utilitária e 'segmentada' (isto é, estreita em seu alcance funcional)” (Guterbock, 1980, p. 7). Quem adere à máquina, de acordo com o modelo de troca material, está "motivado materialmente e responde a incentivos materiais” (Guterbock, 1980, p. 7). Pelo contrário, de acordo com o modelo de troca afetiva, a relação entre votante e mediador é "face a face, pessoal, afetiva e funcionalmente difusa" (Guterbock, 1980, p. 8). Os mediadores políticos oferecem, sim, incentivos para mudar o voto, mas esses incentivos são de um tipo diferente. Como explica Guterbock, "os incentivos específicos que os membros do partido oferecem para mudar o voto são 'solidários' em vez de materiais, e a distribuição de favores é um mecanismo 
por meio do qual os vínculos pessoais podem ser desenvolvidos e mantidos" (Guterbock, 1980, p. 8).

Contudo, os mediadores não anunciam explicitamente que seus favores, bens e informações são oferecidos em um quid pro quo. Pelo contrário, como vimos, negam constantemente o caráter político de seus atos. E essa negação vem junto com uma apresentação da pessoa do mediador: uma performance pública. Os mediadores não apenas acrescentam o monopólio de acesso a recursos e informação. A retórica familiar de Matilde e Pisutti e a rejeição que Andrea sente pelas "grandes soluções" (e sua firme defesa das "pequenas respostas" aos problemas dos pobres) nos levam a explorar uma dimensão pouco conhecida da resolução política dos problemas. Os mediadores não apenas exercem a dominação em virtude de sua posição estrutural, mas também propõem (e tentam ensinar) uma determinada definição cultural da maneira de resolver problemas.

\section{Referências}

BITRAN, Rafael \& SCHNEIDER, Alejandro (1991). El gobierno conservador de Manuel A. Fresco en la provincia de Buenos Aires (1936-1940). Buenos Aires: CEAL.

BOURDIEU, Pierre (1990). In other words: essays towards a reflexive sociology. California: Stanford University Press.

(1991). Language and symbolic power. Cambridge: Harvard University Press.

BOURDIEU, Pierre \& WACQUANT, Loïc (1992). An invitation to reflexive sociology. Chicago: The University of Chicago Press.

BURGWALD, Gerrit (1996). Struggle of the poor neighborhood organization and clientelist practice in a Quito squatter settlement. Amsterdam: CEDLA.

CARLOS, Manuel \& ANDERSON, Bo (1991). "Political brokerage and network politics in Mexico: the case of a dominance system”, em WILLER, David \& ANDERSON, Bo (eds.). Networks, exchange and coercion. The elementary theory and its applications. Nova York: Elsevier.

CONNIFF, Michael L. (1981). Urban politics in Brazil: the rise of populism 1925-1945. Pittsburgh: University of Pittsburgh Press.

CORNELIUS, Wayne A. (1973). "Contemporary Mexico: a structural analysis of urban caciquismo", em KERN, Robert (ed.). The caciques: 
oligarchical politics and the system of caciquismo in the luso-hispanic world. Albuquerque: University of New Mexico Press.

(1977). "Leaders, followers, and official patrons in urban Mexico", em SCHMIDT, Steffen; GUASTI, Laura; LANDÉ, Cari \& SCOTT, James (eds.). Friends, followers, and factions: a reader in political clientelism. Berkeley: The University of California Press.

DURKHEIM, Emile (1984). The division of labor in society. New York: Free Press. ELSON, Diane (1992). "From survival strategies to transformation strategies: women's needs and structural adjustment", em BENERIA, Lourdes \& FELDMAN, Shelley (eds.). Unequal burden: economic crisis, persistent poverty, and women's work. Boulder: Westview.

EPSTEIN, Arnold L. (1969). “The network and urban social organization”, em MITCHELL, J. Clyde (ed.). Social networks in urban situations. Manchester: Manchester University Press.

ERICKSON, Bonnie (1996). “The structure of ignorance”. Discurso inaugural na XVI International Sunbelt Social Network Conference. Charleston, EUA, 22 de fevereiro.

FRASER, Nancy (1989). Unruly practices: power, discourse, and gender in contemporary social theory. Minneapolis: University of Minnesota Press.

FRIEDMAN, John \& SALGUERO, Mauricio (1988). “The barrio economy and collective self-empowerment in Latin America: a framework and agenda for research", em SMITH, Michael Peter (ed.). Power, community, and the city, vol. 1. New Jersey: Transaction.

GAY, Robert (1994). Popular organization and democracy in Rio de Janeiro: a tale of two favelas. Philadelphia: Temple University Press.

GEERTZ, Clifford (1983). Local knowledge. New York: Basic Books.

GOULD, Roger \& FERNÁNDEZ, Roberto (1989). "Structures of mediation: a formal approach to brokerage in transaction networks", em Sociological methodology, n. 19, p. 89-126.

GRAHAM, Carol (1991). “The APRA government and the urban poor: the PAIT programme in Lima’s Pueblos Jóvenes". Journal of Latin American Studies, v. 23, n. 1, p. 91-130.

GRANOVETTER, Mark (1973). “The strength of weak ties”. American Journal of Sociology, n. 78, p. 1360-1380.

GUTERBOCK, Thomas (1980). Machine politics in transition: party and community in Chicago. Chicago: University of Chicago Press. 
HINTZE, Susana (1989). Estrategias alimentarias de sobrevivencia: un estudio de caso en el Gran Buenos Aires. Buenos Aires: CEAL.

SÁNCHEZ JANKOWSKI, Martín (1991). Islands in the streets: gangs and American urban society. California: University of California Press.

KATZNELSON, Ira (1981). City trenches: urban politics and the patterning of class in the United States. Chicago: The University of Chicago Press. KNOKE, David (1990). Political networks. Cambridge: Cambridge University Press.

KORNBLUM, William (1974). Blue collar community. Chicago: The University of Chicago Press.

LEVITSKY, Steve (1997). "Crisis, party adaptation, and regime stability in Argentina”. Conferência apresentada na reunião da Latin American Studies Association. Guadalajara, México, 17 a 19 de abril.

LOMNITZ, Larissa (1975). Cómo sobreviven los marginados. México: Siglo XXI.

(1988). "Informal exchange networks in formal systems: a theoretical model”. American Anthropologist, n. 90, p. 42-55.

MARGULIS, Mario (1981). "Fuerza de trabajo y estrategias de sobrevivencia en una población de origen migratorio: colonias populares de Reynosa”. Demografía y Economía, v. 15, n. 3, p. 265-311.

MINGIONE, Enzo (1991). Fragmented societies: a sociology of economic life beyond the market paradigm. Cambridge: Basil Blackwell.

MOUZELIS, Nicos (1985). "On the concept of populism: populist and clientelist modes of incorporation in semiperipheral polities". Politics and Society, v. 14, n. 3, p. 329-348.

MURPHY, Raymond (1988). Social closure: a theory of monopolization and exclusion. Oxford: Clarendon.

NASON, Marshall R. (1973). "The literary evidence, part III: the caciques in Latin American Literature", em KERN, Robert (ed.). The caciques: oligarchical politics and the system of caciquismo in the luso-hispanic world. Albuquerque: University of New Mexico Press.

MARTÍNEZ NOGUEIRA, Roberto (1995). "Devising new approaches to poverty in Argentina”, em RACZYNSKI, Dagmar (ed.). Strategies to combat poverty in Latin America. Washington: Inter-American Development Bank. 
PAIGE, Karen \& PAIGE, Jeffery M. (1981). The politics of reproductive ritual. Berkeley: University of California Press.

REDFIELD, Robert (1956). Peasant society and culture. Chicago: University of Chicago Press.

ROCK, David (1972). "Machine politics in Buenos Aires and the Argentine Radical Party, 1912-1930". Journal of Latin American Studies, v. 4, n. 2, p. 233-256.

(1975). Politics in Argentina: the rise and fall of radicalism, 18901930. Cambridge: Cambridge University Press.

RONIGER, Luis (1990). Hierarchy and trust in modern Mexico and Brazil. New York: Praeger.

SAHLINS, Marshall D. (1977). "Poor man, rich man, big-man, chief: political types in Melanesia and Polynesia”, em SCHMIDT, Steffen; GUASTI, Laura; LANDÉ, Cari \& SCOTT, James (eds.) Friends, followers, and factions: a reader in political clientelism. Berkeley: University of California Press.

SCHAPIRA, Marie-France Prevot (1996). "Las políticas de lucha contra la pobreza en la periferia de Buenos Aires, 1984-1994”. Revista Mexicana de Sociología, v. 59, n. 2, p. 73-94.

SCOTT, James (1977a). "Political clientelism: a bibliographical essay", em SCHMIDT, Steffen; GUASTI, Laura; LANDÉ, Cari \& SCOTT, James (eds.) Friends, followers, and factions: a reader in political clientelism. Berkeley: University of California Press.

(1977b). “Patronage or exploitation?”, em GELLNER, Ernest \& WATERBURY, John (eds.). Patrons and clients in Mediterranean societies. London: Duckworth.

SILVERMAN, Sydel (1977). "Patronage and community-nation relationships in central Italy”, em SCHMIDT, Steffen; GUASTI, Laura; LANDÉ, Cari \& SCOTT, James (eds.) Friends, followers, and factions: a reader in political clientelism. Berkeley: University of California Press.

SINGERMAN, Diana (1995). Avenues of participation: family, politics, and networks in urban quarters of Cairo. Princeton: Princeton University Press.

STEIN, Steve (1980). Populism in Peru: the emergence of the masses and the politics of social control. Madison: University of Wisconsin Press.

UEHARA, Edwina (1990). "Dual exchange theory, social networks, and 
informal social support". American Journal of Sociology, v. 96, n. 3, p. 521-557.

UGALDE, Antonio (1973). "Contemporary Mexico: from Hacienda to PRI, political leadership in a Zapotec village”, em KERN, Robert (ed.). The caciques: oligarchical politics and the system of caciquismo in the lusohispanic world. Albuquerque: University of New Mexico Press.

WACQUANT, Loïc J. D. (1996). "Dynamics of relegation in advanced societies". Conferência apresentada na International Conference on Globalization and the New Social Inequality. Utrecht, Países Baixos, 20 a 22 de novembro.

WACQUANT, Loïc J. D. \& WILSON, William J. (1989). “The cost of racial and class exclusion in the inner city". The Annals of the American Academy of Political and Social Science, v. 501, n. 1, p. 8-25.

WALTER, Richard (1985). The province of Buenos Aires and Argentine politics, 1912- 1943. Cambridge: Cambridge University Press.

WEBER, Max (1968). Economy and society. Berkeley: University of California Press.

WOLF, Eric R. (1956). "Aspects of group relations in a complex society". American Anthropologist, v. 58, n. 6, p. 1065-1078.

\section{Resumo:}

O artigo analisa a imbricação entre a estrutura do Partido Justicionalista (peronista) e as políticas assistenciais estatais em comunidades pobres da província de Buenos Aires, na época governada por Eduardo Duhalde. Os agentes partidários se colocam na posição de mediadores, que, evitando uma barganha expressa e adotando um discurso de solidariedade, garantem apoio político graças à capacidade de fazer com que carências imediatas sejam supridas. No processo, propõem e buscam disseminar uma determinada forma de resolução de problemas.

Palavras-chave: pobreza; política; peronismo; Argentina.

\section{Abstract:}

The article examines the entangled relations between the structure of Argentina's Justicionalist (Peronist) Party and state welfare policies in poor communities in the province of Buenos Aires, then governed by Eduardo Duhalde. Party agents put themselves in the position of mediators who, avoiding an open bargain and adopting a solidarity-based discourse, guarantee political support thanks to their ability to meet basic needs. In the process, they propose and seek certain ways to solve problems.

Key words: poverty; politics; Peronism; Argentina. 